\title{
LIGHT SOURCE SELECTION FOR A SOLAR SIMULATOR FOR THERMAL APPLICATIONS: A REVIEW
}

\author{
M. Tawfik ${ }^{a, b}$, X. Tonnellier ${ }^{a}$, C. Sansom ${ }^{a}$ \\ ${ }^{a}$ Cranfield University Precision Engineering Institute, School of Aerospace, Transport and Manufacturing, Cranfield University, \\ MK43 OAL, UK \\ ${ }^{\mathrm{b}}$ Mechanical Power Engineering Department, Faculty of Engineering, Mansoura University, 35516, Egypt
}

\begin{abstract}
Solar simulators are used to test components and systems under controlled and repeatable conditions, often in locations with unsuitable insolation for outdoor testing. The growth in renewable energy generation has led to an increased need to develop, manufacture and test components and subsystems for solar thermal, photovoltaic (PV), and concentrating optics for both thermal and electrical solar applications. At the heart of any solar simulator is the light source itself. This paper reviews the light sources available for both low and high-flux solar simulators used for thermal applications. Criteria considered include a comparison of the lamp wavelength spectrum with the solar spectrum, lamp intensity, cost, stability, durability, and any hazards associated with use. Four main lamp types are discussed in detail, namely argon arc, the metal halide, tungsten halogen lamp, and xenon arc lamps. In addition to describing the characteristics of each lamp type, the popularity of usage of each type over time is also indicated. This is followed by guidelines for selecting a suitable lamp, depending on the requirements of the user and the criteria applied for selection. The appropriate international standards are also addressed and discussed. The review shows that metal halide and xenon arc lamps predominate, since both provide a good spectral match to the solar output. The xenon lamp provides a more intense and stable output, but has the disadvantages of being a high-pressure component, requiring infrared filtering, and the need of a more complex and expensive power supply. As a result, many new solar simulators prefer metal halide lamps.
\end{abstract}

\section{Keywords}

Solar simulator, sunlight, solar spectrum, CSP, metal halide, tungsten lamp

\section{Introduction}

The growing demand for energy, combined with issues of environmental pollution, climate change, and the rapid depletion of fossil fuels, have encouraged the research and development of cost effective renewable alternatives [1-3]. Solar electrical and thermal energy research groups have focused on developing novel technologies and on improving existing renewable solutions. In 2014, the global combined installed capacity of solar hot water and concentrating solar power (CSP) was $410.4 \mathrm{GW}$, representing $8 \%$ of the world's renewable energy sources [4].

The transient nature of solar energy represents a critical challenge for technologies testing. Outdoor experiments are carried out in real but uncontrollable environments. For example, incident solar energy levels are highly dependent on atmospheric conditions and sky clarity over time [5]. Therefore, achieving 
the rapid and low-cost development of solar thermal and PV systems requires a controlled environment with key parameters that can be adjusted and monitored. Consequently, a range of solar simulators have been designed and used since the 1960's.

A solar simulator is a device with a light source which offers both an intensity level and a spectral composition close to that of natural sunlight [6]. It is used to simulate either extra-terrestrial or terrestrial radiation [7]. Early solar simulators were designed and built in the 1960's to be used in space applications research projects sponsored by the National Aeronautics and Space Administration (NASA) for spacecraft ground-testing by simulating environments at orbital altitudes [8-10]. More recently, research work has focused on terrestrial radiation simulators. These devices are used for a wide range of applications including testing, calibrating and characterising photovoltaic (PV) cells [11-14] and for the clinical testing of sunscreens [15-17]. The list of applications extends to the automotive industry for testing dashboards, steering wheels and air bags [18-20]; PV materials ageing tests [21-24]; studying the effects of light on the growth of plants and algae [25-27] and testing of thermal/thermo-chemical devices for use in the chemical reforming and production of chemical elements [28-30]. This paper deals with solar simulators built for thermal applications, although they are also relevant to PV and concentrating PV (CPV) testing [31-35]. More applications are covered in section 3. Such simulators have output fluxes ranging from a few suns ( 1 sun $=1 \mathrm{~kW} / \mathrm{m}^{2}[36-38]$ ), to more than 30 suns, which are classified as low and high-flux solar simulators, respectively [39]. Those simulators consist of three main parts: a light source, a power supply and an optical component. Each part is selected to obtain a controlled output conforming to specific requirements. The current work focuses on the selection of a suitable light source, which is critical to ensure simulated solar radiation quality and reliability [40].

\section{Standard Solar Spectrum}

\subsection{Blackbody radiator spectrum}

A blackbody is an idealised object which is a perfect radiation emitter and absorber [41]. A blackbody radiator has the maximum possible spectral radiance for a heated body at a particular specified temperature. Therefore, this temperature is usually used as a convenient baseline for comparison with real radiation sources [42]. The sun can be considered as a blackbody radiator at a temperature of $5777 \mathrm{~K}$, which can be approximated to 5800K [43-46]. Spectral radiance of a blackbody can be determined, in W. $\mathrm{m}^{-3} \cdot \mathrm{sr}^{-1}$, by applying Planck's law [47]:

$$
E_{\lambda}=\left(2 h c^{2} / \lambda^{5}\right)\left(e^{h c / \lambda k T}-1\right)^{-1}
$$

Where $h$ is Planck's constant $\left(6.6262 \times 10^{-34} \mathrm{~J} . \mathrm{s}\right), c$ is the velocity of light $\left(2.9979 \times 10^{8} \mathrm{~m} / \mathrm{s}\right), \lambda$ is the wavelength $(\mathrm{m}), k$ is the Boltzmann's constant $\left(1.3806 \times 10^{-23} \mathrm{~J} / \mathrm{K}\right)$, and $T$ is absolute temperature $(\mathrm{K})$.

\subsection{Solar spectrum}

The actual solar spectrum differs from a blackbody radiance at $5800 \mathrm{~K}$ because of absorption in the cool peripheral solar gas (Fraunhofer lines) $[72,73]$. While passing through the Earth's atmosphere, direct solar radiation is attenuated by scattering and absorption by gaseous molecules (i.e. nitrogen, oxygen, aerosols and water vapour) [50]. Therefore, an Air Mass (AM) coefficient has been defined to characterise the solar spectrum after the solar radiation has travelled through the atmosphere [51]. The 
AM coefficient is defined as the ratio of the solar radiation path length through the atmosphere $(L)$, incident at a zenith angle $(z)$, and the atmosphere thickness in the zenith direction $\left(L_{0}\right)$ [52]:

$$
A M=L / L_{0}=1 / \cos Z
$$

Although this relation can be refined by modelling more accurate path thicknesses through the horizon [53-55], equation (2) remains commonly used to define standard conditions for solar applications. It is expressed using the syntax "AM" followed by its value [51]. The variation between different AM definitions (i.e. AM0, AM1.0 and AM1.5) is illustrated in Fig. 1.

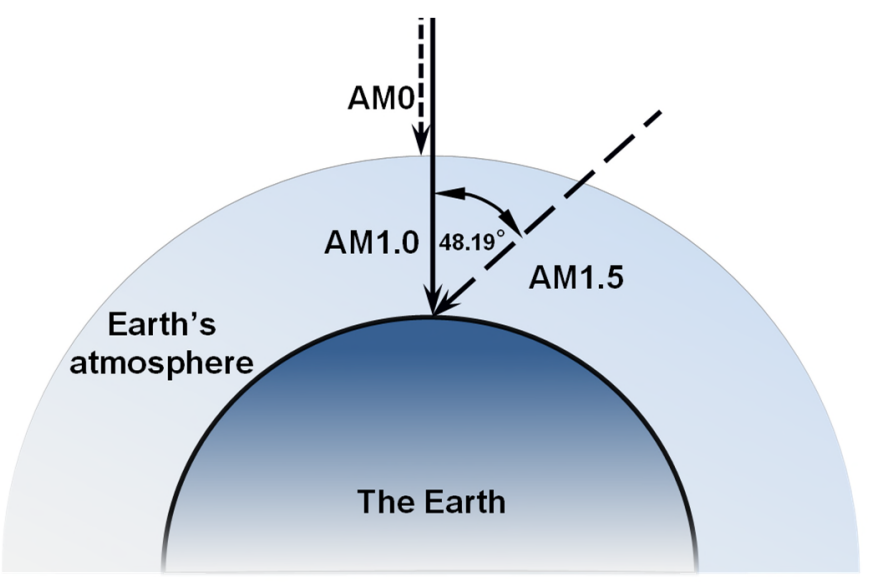

Fig. 1. Air Mass (AM) definition (adapted from [56])

The extra-terrestrial solar spectrum (AM0) is used to characterise PV panels used for space applications [57]. There are various solar irradiance spectra constructed from single and/or multiple measurement sets or models [58,59]. However, for space solar power applications, the standard ASTM E490 [60] is usually applied. The solar spectrum travelling through the atmosphere directly to sea level with a zenith angle of zero (AM1.0) is published by ASHRAE [61]. As solar panels and collectors operate at tilted angles, the solar radiation path is greater than one atmosphere's thickness [57]. Since the world's major solar installations and industry centres are located [62] at mid-latitudes, a specific AM number was defined for a zenith angle of $48.19^{\circ}$. Since the 1970s, AM1.5 has been used for standardisation purposes [63-65] provided by ASTM G173-03 standard; previously ASTM G159-98 [66,67].

The solar spectrum is divided into three main regions: ultraviolet (UV), visible, and infrared (IR) with wavelength ranges of $<400 \mathrm{~nm}, 400-760 \mathrm{~nm}$, and $>760 \mathrm{~nm}$ respectively [68]. According to the International Commission on Illumination (CIE), the UV region can be defined in three bands: UV-A (315-400nm), UV-B (280-315nm) and UV-C (100-280nm) [69,70]. Fig. 2 shows a comparison between different solar spectra and the radiation spectrum of a blackbody at $5800 \mathrm{~K}$. The differences between the spectrum curves in Fig. 2 are attributed to the attenuation and transmission losses of sunlight over its optical path through the Earth's atmosphere. Therefore, the longer optical path shows the least spectral irradiance. However, data plotted in Fig. 2 confirms the assumption of treating the sun as a blackbody radiator at $5800 \mathrm{~K}$. 


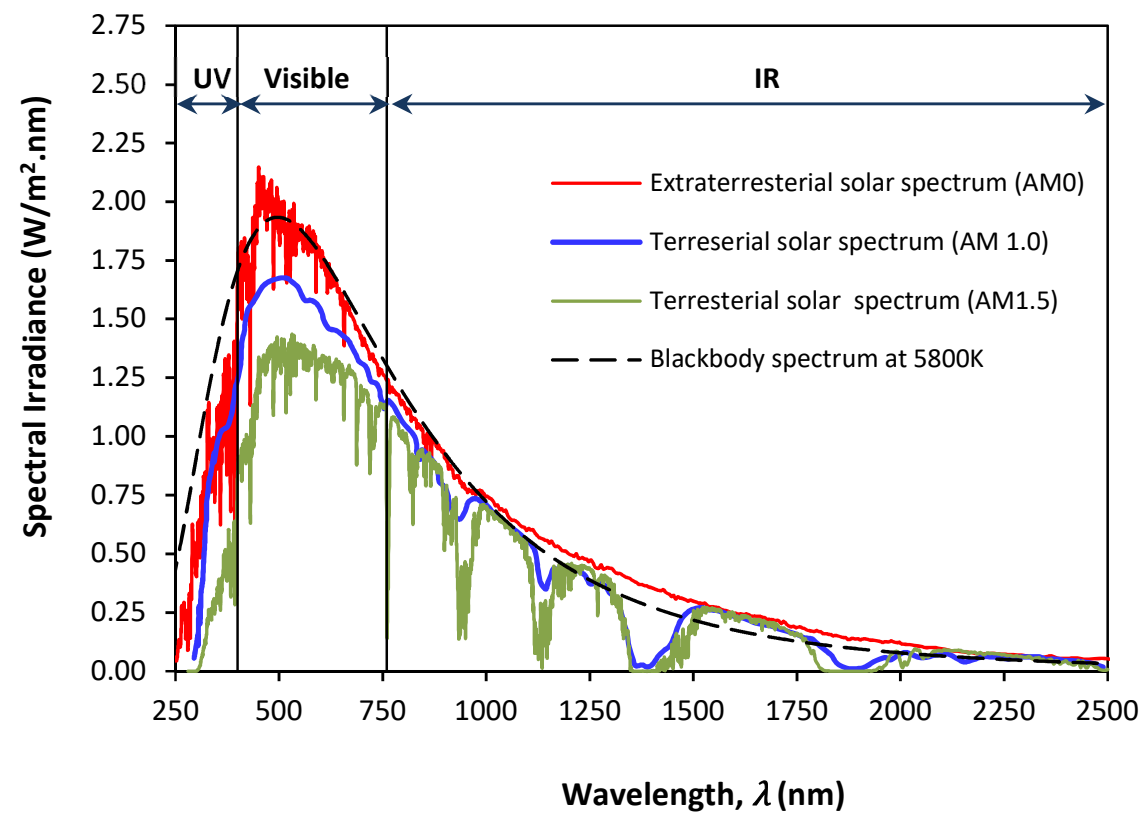

Fig. 2. Comparison between solar spectra (AM0 [60], AM1.0 [61], AM1.5 [66]) and black body radiator spectrum [71]

\section{Light sources}

Light source selection is the principal step in designing a solar simulator with suitable simulated solar radiation. This light source is required to meet several criteria: spectral quality, illumination uniformity, collimation, flux stability and a range of obtainable flux [72].

Various lamp types have been employed in solar simulators, including carbon arc, metal halide, tungsten halogen, xenon arc, mercury xenon, high pressure sodium vapour, argon arc and light-emitting diode lamps (LED) [33]. The choice can depend on the field of application of the solar simulator. For example, the optimum output current of a PV cell is generated when the incident spectrum matches with the spectral absorption properties of the semiconductor [107] and are more sensitive to the incident light spectrum below $1000 \mathrm{~nm}$ for a silicon PV cell [33,73-76]. Multi-junction PV cells are more sensitive to the spectrum of the light source which affects their fill factor and short-circuit resistance [77]. Therefore, researchers tended to use multi-light source synthesis to improve the spectral matching for PV performance testing. These simulators employ either conventional light sources, such as xenon arc and tungsten lamps [78-80], or multiple LEDs with an adjustable emitted spectrum [81-83]. Due to this sensitivity, different classification standards of solar simulators for PV testing have been developed to classify solar simulators. These standards were developed by the International Electrotechnical Commission (i.e. IEC 60904-9), and also the American Society for Testing and Materials (i.e. ASTM E927, ASTM E948, ASTM E1036, ASTM E1362), and include Japanese Industrial Standards (i.e. JIS C 8912) and British Standards (i.e. EN 60904) [84-90].

For solar simulators used in terrestrial thermal applications, the principal parameters determined are: the peak flux, the total beam power and the flux density distribution [91]. They are less sensitive to the incident spectrum in the UV and visible compared to the IR spectrum part, as infrared represents most of the thermal radiation emitted by terrestrial objects [92-94]. Therefore, a mono-light source type is 
usually employed with single or multiple lamp configurations. Moreover, the low sensitivity to the light source output spectrum minimises lamp's specifications requirements defined by standards related to solar thermal applications, including the International Standards (ISO 9806, ISO 19467) and British Standards (i.e. EN 12975-1, EN 12975-2, EN 12976-1 and EN 12976-2) [95-100].

For these simulators, the selected lamp types are usually argon arc, metal halide, tungsten halogen or xenon arc.

\subsection{Argon arc lamp}

The Argon arc lamp is a free-burning DC powered device [101]. The pressurised argon gas (with approximate pressure of 7-10 bar [102-104]) enters at the cathode end, swirls along the central core until it exits at the anode end. In order to cool the arc edge, a sheet of water is created by swirling a high flow rate water vortex along the inside quartz tube wall with pressure over 60 bar at the inlet $[108,110]$, as shown in Fig. 3.

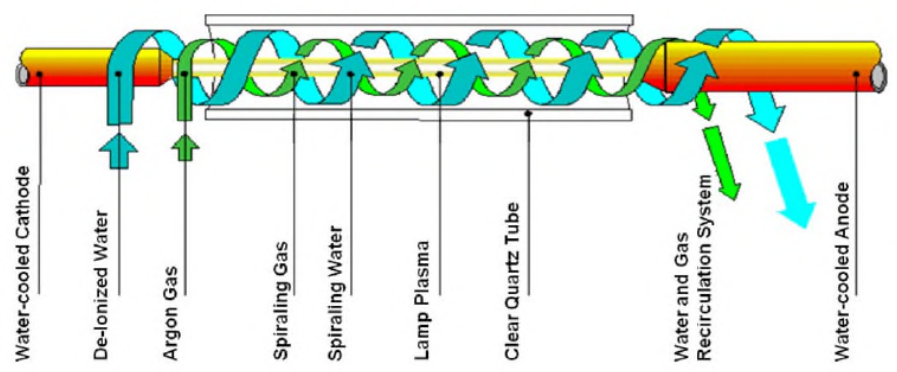

Fig. 3. Schematic of vortex water-wall argon arc lamp [111, 112]

These lamps have been used since the 1970s [108, 113-115] in the solar simulation field as well as in laser applications [111].

\subsection{Metal halide lamp}

In a metal halide lamp, the light is produced by an electric arc which is generated through a gaseous mixture of vaporized mercury and metal halide compounds under a high pressure ranging from 10 to 35 bar [112-114]. It is a type of high-intensity discharge (HID) gas lamp [115], as illustrated in Fig. 4.

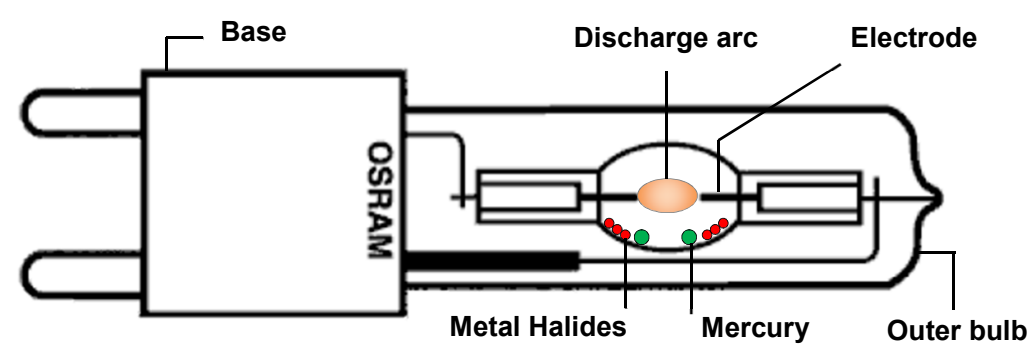

Fig. 4. Metal halide lamp structure (adapted from [116,117])

Metal halide lamps were introduced as a light source option for solar simulation after the development of compact source iodide (CSI) metal halide lamps [6]. Those CSI lamp types have high efficiency, a balanced spectral quality closely matching sunlight, long lifetime and relative low cost. Therefore, many researchers selected them for their simulators [31,118-126]. Other types of metal halide lamps have also been tested $[7,39,72,127-137]$. 


\subsection{Tungsten halogen lamp}

A Tungsten halogen lamp is a type of incandescent lamp which contains a halogen in the form of bromine or iodine surrounding a tungsten filament heated by an electric current $[138,139]$, as shown in Fig. 5.

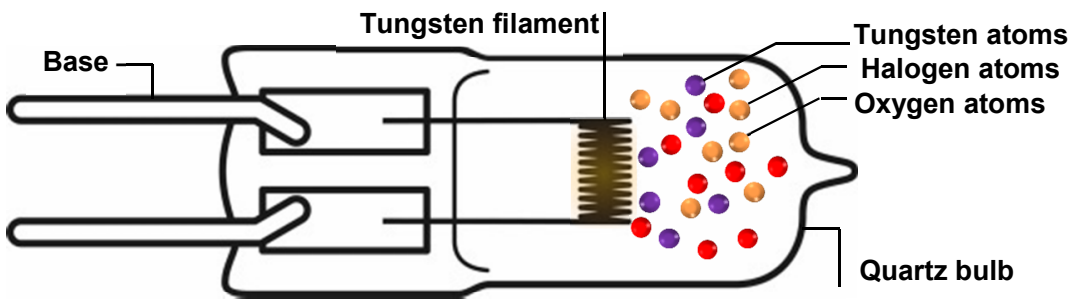

Fig. 5. Tungsten halogen lamp structure (adapted from $[140,141]$ )

While incandescent lamps have a maximum colour temperature of 3400K [142], according to the Wien displacement law [143], these lamps radiate weaker in the ultraviolet and stronger in the infrared regions compared to the solar spectrum with its colour temperature of 5800K [44-46]. Despite this disadvantage, tungsten halogen lamps have been utilised in solar simulation [123, 129, 150-157]. This may be attributed to their excellent light output and relatively low cost [152]. They are widely used in less spectrum-sensitive applications such as concentrated solar collector testing and as an infrared light source in multi-source solar simulators [6].

\subsection{Xenon arc lamp}

The Xenon arc lamp is a type of HID gas discharge lamp in which light is produced by passing an electric arc through ionized xenon gas under high pressure ranging from 10 to 40 bar $[6,159,160]$, as shown in Fig. 6.

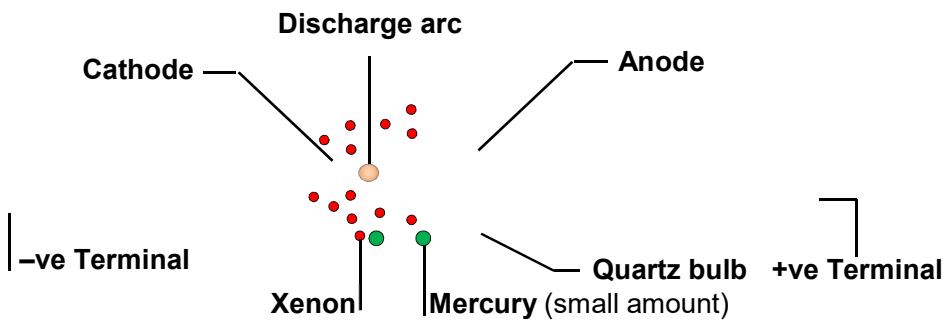

Fig. 6. Xenon arc lamp structure (adapted from [155-157])

These lamps are often preferred by manufacturers and researchers as a light source for solar simulators $[6,39,40,62,98,123,164-179]$. They benefit from an excellent quality and stable spectrum in the UV and visible bands. Their strong emission in the IR range can be filtered [142] if required. Moreover, a collimated high intensity light beam can be generated as a result of a brighter point source than other light sources [176]. However, operation of these lamps under high pressure creates an increased risk of explosion [177]. In addition, the UV radiation emitted by these lamps can generate ozone, which can create a respiratory hazard [178]. Besides health and safety concerns, their high cost and output sensitivity to power supply instabilities represent significant drawbacks that need to be carefully considered before using them in solar simulators $[6,39,142,176]$. 


\subsection{Trends in using light sources}

Table 1 summarises a list of thermal solar simulators details published in literature.

Table 1. Comparison of different thermal solar simulators (chronological order)

\begin{tabular}{|c|c|c|c|c|c|c|}
\hline $\begin{array}{l}\text { Lamp } \\
\text { type }\end{array}$ & $\begin{array}{l}\text { Lamp } \\
\text { power } \\
\left(k_{\mathrm{e}}\right) \\
\end{array}$ & $\begin{array}{l}\text { Number of } \\
\text { lamps }\end{array}$ & $\begin{array}{l}\text { Total output } \\
\text { flux }\left(\mathrm{kW}_{\mathrm{r}} / \mathrm{m}^{2}\right)\end{array}$ & $\begin{array}{c}\text { Spot } \\
\text { dimensions } \\
(\mathrm{m})\end{array}$ & $\begin{array}{c}\text { Calculated } \\
\text { conversion } \\
\text { efficiency }^{1}(\%)\end{array}$ & Reference(s) \\
\hline \multirow{5}{*}{ 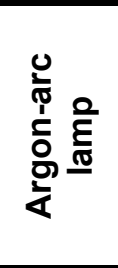 } & $400 \mathrm{DC}$ & 2 & 1.21 & $4.6 \times 9.2$ & 6.42 & [103] \\
\hline & $100 \mathrm{DC}$ & 1 & $0.25-1.25$ & $1.5 \times 0.50$ & 0.94 & [108] \\
\hline & $100 \mathrm{DC}$ & 1 & 1 & $1.5 \times 0.50$ & 0.75 & [109] \\
\hline & $150 \mathrm{DC}$ & 1 & 6680 & $\varnothing 0.01905$ & 1.27 & {$[179,180]$} \\
\hline & $200 \mathrm{DC}$ & 1 & 4250 & $\varnothing 0.06$ & 6.01 & {$[110,181]$} \\
\hline \multirow{21}{*}{ 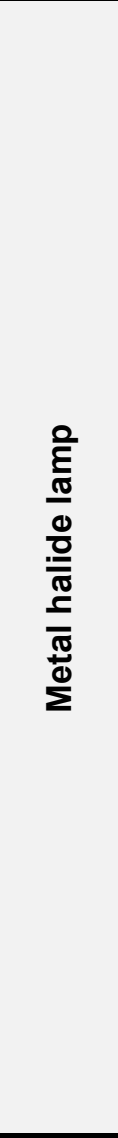 } & 1 & 19 & $0.4-0.9$ & $\varnothing 2.25$ & 18.83 & [127-129] \\
\hline & 1 & 36 & $0.2-1.1$ & $2 \times 2$ & 12.22 & {$[31,118]$} \\
\hline & 1 & 36 & $1-1.2$ & $1.2 \times 2.4$ & 9.60 & [118] \\
\hline & 1 & 27 & $0.6-1$ & $1.5 \times 1.8$ & 10.00 & [119] \\
\hline & 1 & 55 & 0.865 & $2.5 \times 2.3$ & 9.04 & {$[120,121,126]$} \\
\hline & 1 & 72 & $0.4-0.8$ & $3 \times 3$ & 10.00 & {$[122]^{2}$} \\
\hline & 1 & 40 & $0.7-1$ & $1.4 \times 3$ & 10.50 & [123] \\
\hline & 1 & 28 & $0.983-1.188$ & $1.06 \times 1.06$ & 4.77 & {$[124,125]$} \\
\hline & 1 & 18 & - & - & - & {$[72,130]$} \\
\hline & 1.5 & 7 & 60 & $\varnothing 0.38$ & 64.81 & {$[39,131]$} \\
\hline & 1.2 & 1 & $0.8-1$ & - & - & {$[132,133]$} \\
\hline & 0.4 & 188 & $0.15-1.1$ & $4.5 \times 3.88$ & 25.54 & [7] \\
\hline & 6 & 1 & 112 & $0.095 \times 0.095$ & 16.85 & [134] \\
\hline & 6 & 7 & 927 & $\varnothing 0.175$ & 53.09 & [135] \\
\hline & 2.5 & 6 & - & $50 \times 0.4$ & - & [136] \\
\hline & 1.2 & 15 & 1 & $2.5 \times 1.5$ & 20.83 & [32] \\
\hline & - & 35 & 0.8 & - & - & [182] \\
\hline & 0.575 & 35 & 1.2 & $1.8 \times 2.2$ & 23.61 & {$[183,184]$} \\
\hline & 0.4 & 88 & $0.15-1$ & $1.6 \times 1.6$ & 7.27 & [185] \\
\hline & $1 \& 2$ & $\begin{array}{c}6 \times 1 \mathrm{~kW} \& \\
6 \times 2 \mathrm{~kW}\end{array}$ & $0.1-1$ & $2.8 \times 2.7$ & 42.00 & [186] \\
\hline & 4 & 32 & 1 & $11 \times 9.2$ & 79.06 & [137] \\
\hline \multirow{9}{*}{ 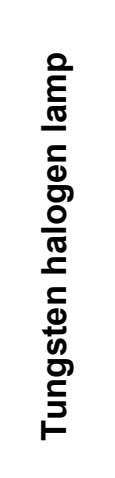 } & 0.3 & 143 & $0.61-1.05$ & $1.2 \times 1.2$ & 3.52 & \multirow{2}{*}{ [144-146] } \\
\hline & 0.3 & 12 & $0.102-0.55$ & $1.2 \times 1.2$ & 22.00 & \\
\hline & 0.3 & 405 & $0.395-0.962$ & $2 \times 3$ & 4.75 & [147] \\
\hline & 0.3 & 187 & $0.5-1.1$ & $1.2 \times 1.8$ & 4.24 & [118] \\
\hline & 0.3 & 200 & $0.5-1.46$ & $(1.6 \mathrm{~m} 2)$ & 3.89 & [118] \\
\hline & 0.15 & 10 & 0.8 & $0.12 \times 0.50$ & 3.20 & \multirow{2}{*}{ [148] } \\
\hline & 0.15 & 15 & 1.8 & $0.40 \times 0.60$ & 19.20 & \\
\hline & 0.3 & 96 & $0.7-1$ & $1.4 \times 3$ & 14.58 & [123] \\
\hline & 1 & 14 & $0.4-1.5$ & $1 \times 1$ & 10.71 & [149] \\
\hline
\end{tabular}

1 Energy conversion is defined and explained later in detail in section 4.5.

2 Their measurements indicated that $143 \mathrm{klx}$ is equivalent to $1 \mathrm{~kW} / \mathrm{m}^{2}$, while it was reported that $139 \mathrm{klx}$ corresponds $1 \mathrm{~kW} / \mathrm{m}^{2}$ [152]. 


\begin{tabular}{|c|c|c|c|c|c|c|}
\hline $\begin{array}{l}\text { Lamp } \\
\text { type }\end{array}$ & $\begin{array}{l}\text { Lamp } \\
\text { power } \\
\left(k W_{e}\right)\end{array}$ & $\begin{array}{l}\text { Number of } \\
\text { lamps }\end{array}$ & $\begin{array}{l}\text { Total output } \\
\text { flux }\left(\mathrm{kW}_{\mathrm{r}} / \mathrm{m}^{2}\right)\end{array}$ & $\begin{array}{c}\text { Spot } \\
\text { dimensions } \\
(m)\end{array}$ & $\begin{array}{c}\text { Calculated } \\
\text { conversion } \\
\text { efficiency }^{1}(\%)\end{array}$ & Reference(s) \\
\hline & 0.74 & 6 & 25 & $\varnothing 0.1524$ & 10.27 & [150] \\
\hline & 0.3 & 45 & 0.6 & $1.2 \times 2.4$ & 12.80 & [187] \\
\hline & 0.3 & 20 & $0.5-0.645$ & $2 \times 0.46$ & 9.89 & [188] \\
\hline & 1 & 4 & $5.38-7.094$ & - & - & {$[189,190]$} \\
\hline & 0.3 & 2 & $0.425-0.918$ & $\varnothing 0.12$ & 1.73 & [191] \\
\hline & $0.3 \& 0.5$ & $\begin{array}{c}4 \times 0.3 \mathrm{~kW} \& \\
12 \times 0.5 \mathrm{~kW}\end{array}$ & 0.63 & $1.9 \times 0.55$ & 9.14 & [192] \\
\hline & 0.4 & 30 & $0.2-1.2$ & $1.45 \times 1.6$ & 23.20 & [151] \\
\hline \multirow{23}{*}{ 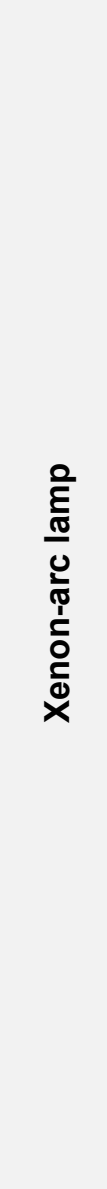 } & 20 & 7 & $0.135-2.95$ & $\sim \varnothing 3.05$ & 15.40 & [118] \\
\hline & 6.5 & 10 & $0.1-1.7$ & $\varnothing 1.6$ & 5.26 & {$[118,159]$} \\
\hline & 20 & 1 & 3,000 & $\varnothing 0.015$ & 2.65 & [158] \\
\hline & 6 & 10 & 4100 & $\sim \varnothing 0.11$ & 64.94 & {$[91,161,162]$} \\
\hline & 30 & 9 & 1.7 & $\varnothing 4.8$ & 11.39 & {$[160,193]$} \\
\hline & 15 & 10 & 6800 & $\varnothing 0.06$ & 12.82 & \multirow{2}{*}[163,164,194,195]{} \\
\hline & 15 & 10 & 11,000 & $\varnothing 0.003$ & 0.05 & \\
\hline & 5 & 1 & 10 & $\sim \varnothing 0.20$ & 6.28 & [165] \\
\hline & 6.5 & 7 & $3250-3700$ & $\varnothing 0.06$ & 22.99 & [166-168] \\
\hline & 7 & $1-12^{3}$ & 54 & $\varnothing 0.30$ & 54.53 & [169] \\
\hline & 6 & 7 & 4230 & - & - & [170] \\
\hline & 7 & 12 & 627 & $\varnothing 0.20$ & 23.45 & {$[171,175]$} \\
\hline & 7 & 1 & 43.2 & $\varnothing 0.11$ & 5.86 & [33] \\
\hline & 6 & 7 & 1860 & $\varnothing 0.06$ & 12.52 & {$[172,173]$} \\
\hline & 7 & 19 & 735-1100 & $\varnothing 0.2$ & 25.98 & [196] \\
\hline & 7 & 1 & 329 & $0.06 \times 0.06$ & 16.92 & [197] \\
\hline & 3 & 1 & 100 & $0.06 \times 0.06$ & 12.00 & \multirow{2}{*}[34,198-200]{} \\
\hline & 3 & 1 & 1200 & $0.005 \times 0.005$ & 1.00 & \\
\hline & 10 & 1 & 10,000 & $\varnothing 0.01$ & 7.85 & {$[201,202]$} \\
\hline & 1 & 6 & $0.05-0.8$ & - & - & [203] \\
\hline & 30 & 9 & 1.8 & $\varnothing 4.79$ & 12.01 & [204-207] \\
\hline & 3 & 1 & 3.675 & $\varnothing 0.91$ & 79.67 & [208] \\
\hline & 5 & 20 & $18-24.3$ & $0.4 \times 0.07$ & 0.68 & [174] \\
\hline
\end{tabular}

Using data listed in Table 1, solar simulators were categorised based on their year of construction (tenyear era) and the lamp type selected (Fig. 7).

${ }^{3}$ [169] carried out theoretical study based on 12 lamps, while experiments were reported on a single lamp. 


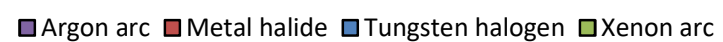

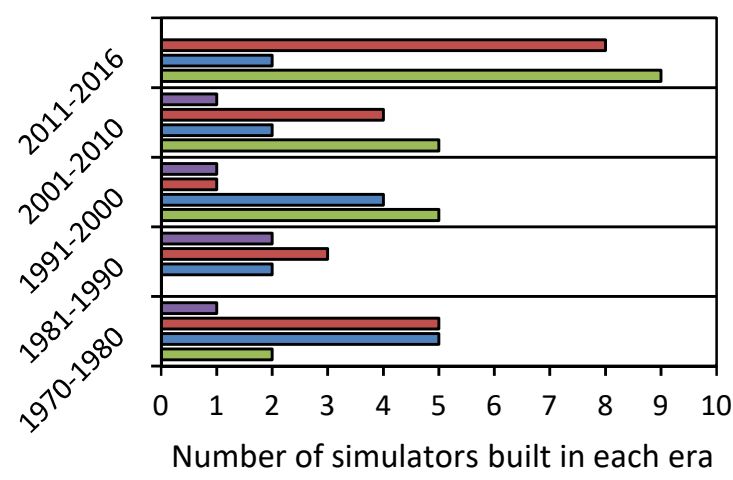

(a) Number of simulators built in each era $\square$ Argon arc $\square$ Metal halide $\square$ Tungsten halogen $\square$ Xenon arc

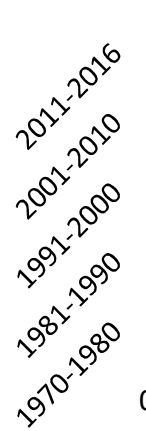

(b) Percentage of usage in each era

Fig. 7 Light sources usage share in different eras

The number of simulators built in each era and usage percentages per era are shown in Fig. 7a and Fig. $7 \mathrm{~b}$ respectively. The participation share over the period from 1970 to 2016, based on 62 cases listed in Table 1, showed that the most popular lamp types are metal halide and xenon arc lamps with usage share of $34 \%$ each, while $24 \%$ of listed cases used tungsten halogen lamps. It can be observed that in 1970-80s, researchers used principally low-cost and available tungsten halogen and metal halide lamps rather than xenon or argon arc lamps. In 1990-2000s, xenon arc lamps competed with other types because of their excellent performance and high-quality output spectrum. From 2000s, metal halide lamps have made a resurgence compared to tungsten halogen lamps. This may be attributed to receding argon arc lamps usage since 2005 as a result of the acquisition of Vortek Industries Ltd., the main historical supplier of argon arc lamps [209].

\section{Guidelines for the selection of a light source}

The design of a solar simulator can be divided into three major steps: 1) defining system output requirements, 2) reviewing different light sources with their characteristics and 3) processing data from previous steps to obtain the required design parameters needed to complete the final simulator design. A flowchart that can be used as a guideline is shown in Fig. 8.

First, the desired output flux, target area and the sensitivity to spectrum are defined. The light source output spectrum, availability, characteristics and requirements, cost and conversion efficiency are defined. Finally, a decision is made based on interactions between elements from the previous steps. The following subsections focus on the second step by reviewing each light source output spectrum, availability, characteristics and requirements, cost and conversion efficiency. 


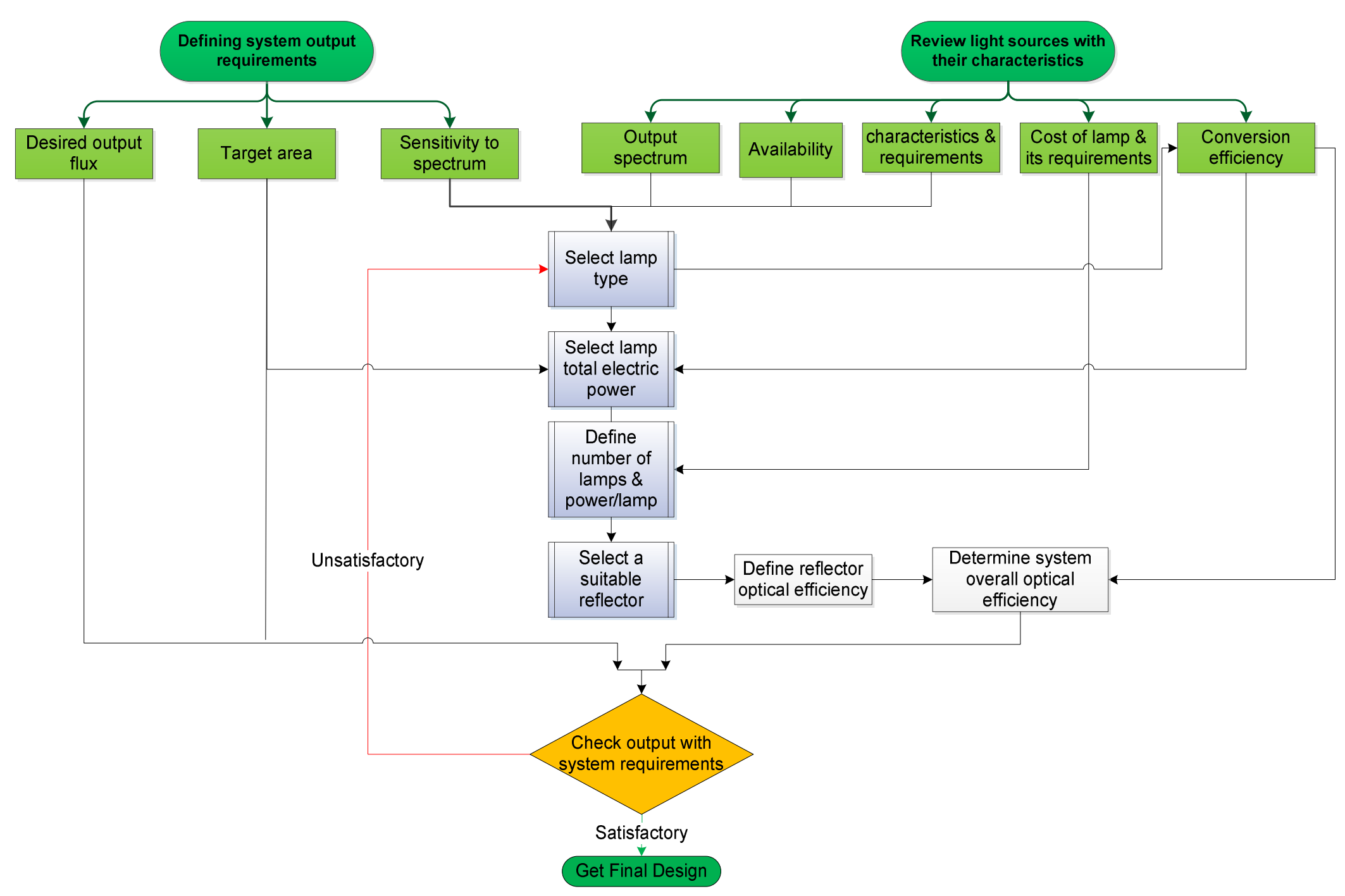

Fig. 8 Flow chart of major steps of light source selection in the design of a solar simulator 


\subsection{Light sources standard requirements}

For light sources employed in solar simulators used for thermal applications, some parameters are required to meet the standard values listed in International and British Standards (ISO 9806, ISO 19467, EN 12975-1, EN 12975-2, EN 12976-1 and EN 12976-2) [95-100]. These parameters include spectral quality, collimation, flux magnitude and range of obtainable flux.

\subsubsection{Spectral quality}

The solar spectrum at optical air mass AM1.5 provided by the ASTM G173-03 standard [66] is used as a reference standard to compare the spectral distribution of the simulated solar radiation against that of the actual solar spectrum. The irradiance at a point on the tested specimen aperture area should not deviate from the mean irradiance over the gross area by more than $\pm 15 \%$ [95].

\subsubsection{Collimation}

Generally, the collimation condition of the simulated solar radiation is considered to be satisfied if at least $80 \%$ of the simulated solar irradiance received at any point on the tested specimen area has emanated from a region of the solar irradiance simulator contained within a subtended angle of $60^{\circ}$ or less when viewed from any point [95]. However, these limits change in the case of measuring the incidence angle modifier (IAM) ${ }^{4}$. For this case, the collimation condition can be satisfied by at least $90 \%$ of the simulated solar radiation received at any point on the tested specimen area having emanated from a region of the solar irradiance simulator contained within a subtended angle of $20^{\circ}$ or less. In other words, the maximum angle of irradiance to the test specimen in this case is required to be within $20^{\circ}$ $[95,96,99,100]$

\subsubsection{Flux magnitude}

For the output irradiance magnitude, the light source is required to be capable of producing a mean irradiance over the plane of the tested specimen aperture greater than $700 \mathrm{~W} / \mathrm{m}^{2}[95,97,98]$. However, in some specialized tests, values of mean irradiance required may be in the range $300 \mathrm{~W} / \mathrm{m}^{2}$ to $1000 \mathrm{~W} / \mathrm{m}^{2}$. The permitted deviation of measured global test solar irradiance from the mean value should be in the range of $\pm 50 \mathrm{~W} / \mathrm{m}^{2}[95]$.

\subsubsection{Range of obtainable flux}

The effective irradiance width and height is required to be $100 \%$ or greater than each dimension of the test specimen width and height [96]. Table 2 summarises standard values and limits for the specified parameters.

\footnotetext{
${ }^{4}$ The incidence angle modifier (IAM), represents the effect of the incidence angle on the optical efficiency and useful aperture area [245]. It corresponds to the decrease in the actual irradiance reaching the tested area with respect to irradiance under normal incidence, due to increasing refection losses with the incidence angle [246].
} 
Table 2 Standard values and limits for different solar simulator parameters

\begin{tabular}{|c|c|c|c|}
\hline Parameter & Value limit & Standard(s) & Reference(s) \\
\hline $\begin{array}{l}\text { Spectral } \\
\text { quality }\end{array}$ & $\begin{array}{l} \pm 15 \% \text { from the mean irradiance over the gross } \\
\text { area }\end{array}$ & ISO 9806 & [95] \\
\hline \multirow{2}{*}{ Collimation } & $\begin{array}{l}\text { General: } \geqslant 80 \% \text { of simulated irradiance } \\
\text { contained within an angle of } 60^{\circ}\end{array}$ & ISO 9806 & {$[95]$} \\
\hline & $\begin{array}{l}\text { IAM test: } \geqslant 90 \% \text { of simulated irradiance } \\
\text { contained within an angle of } 20^{\circ}\end{array}$ & $\begin{array}{l}\text { ISO } 9806 \text {, } \\
\text { ISO 19467, } \\
\text { EN 12976-1, } \\
\text { EN 12976-2 }\end{array}$ & {$[95,96,99,100]$} \\
\hline \multirow{2}{*}{$\begin{array}{l}\text { Flux } \\
\text { magnitude }\end{array}$} & Mean irradiance: $\geqslant 700 \mathrm{~W} / \mathrm{m}^{2}$ & $\begin{array}{l}\text { ISO } 9806 \text {, } \\
\text { EN 12975-1, } \\
\text { EN 12975-2 }\end{array}$ & {$[95,97,98]$} \\
\hline & $\begin{array}{l}\text { Permitted deviation: } \pm 50 \mathrm{~W} / \mathrm{m}^{2} \text { from the mean } \\
\text { global test solar irradiance }\end{array}$ & ISO 9806 & [95] \\
\hline Flux range & $\begin{array}{l}\text { Effective irradiance area } \geqslant 100 \% \text { of tested } \\
\text { specimen area }\end{array}$ & ISO 19467 & {$[96]$} \\
\hline
\end{tabular}

\subsection{Light sources spectra}

Although thermal applications have a lower sensitivity to the light source spectrum than PV applications, a high spectral quality is preferable $[212,213]$. The thermal response of a material varies with the incident radiation due to its spectral reflectance, transmittance, and absorption [214, 215]. A lamp can be characterised by its colour temperature. This value corresponds to a blackbody radiator temperature with a maximum irradiance which is obtained at the same wavelength as the light source [20, 216]. The colour temperatures of different light sources selected in thermal solar simulators (Table 1) are listed in Table 3.

Table 3 Colour temperatures of different light sources (based on available values)

\begin{tabular}{lcc}
\hline \multicolumn{1}{c}{ Light source } & Colour temperature (K) & Reference(s) \\
\hline Sun & $5777($ 5800) & {$[43-46]$} \\
\hline Argon arc lamp & 6500 & {$[216]$} \\
\hline Metal halide lamp & $4000-6000$ & {$[55,137-139,141,143]$} \\
\hline Tungsten halogen lamp & $2100-3350$ & {$[150-154,157]$} \\
\hline Xenon arc lamp & 6000 & {$[39,62,98,166,167,171-173,175,218]$} \\
\hline
\end{tabular}

However, light sources with the same colour temperature can vary significantly in the emitted irradiance distribution [218]. The spectrum of each lamp type can be compared with the standard solar spectrum (AM1.5), as illustrated in Fig. 9. 


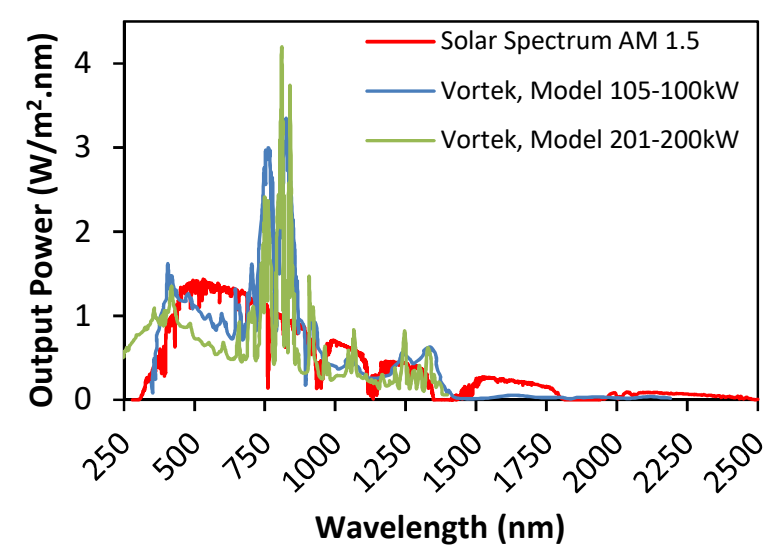

(a) Argon arc lamp $[109,110]$

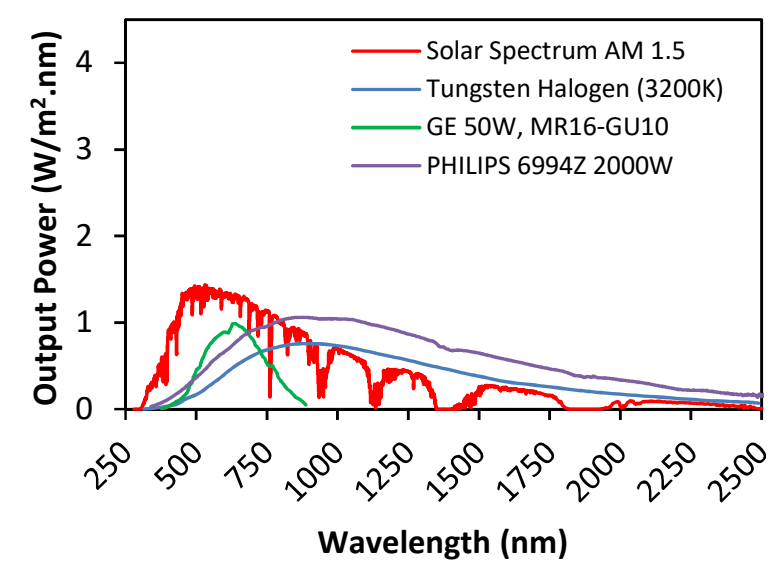

(c) Tungsten halogen lamp [219-221]

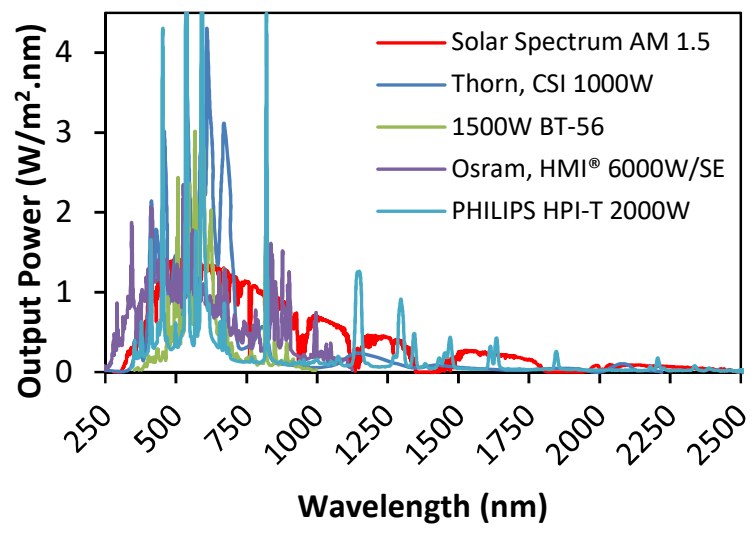

(b) Metal halide lamp $[39,118,167]$

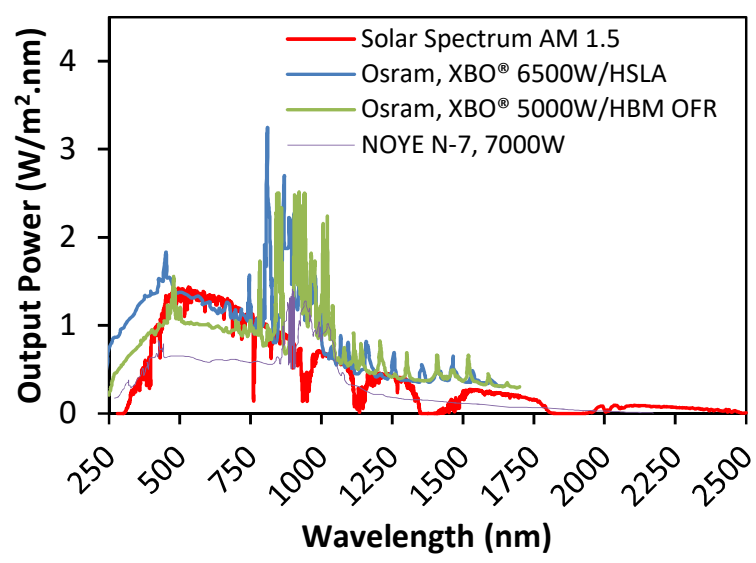

(d) Xenon arc lamp $[165,167,171,175]$

Fig. 9 Different light sources spectra versus solar standard spectrum [66]

Although argon arc lamps (Fig. 9a) do not emit in the IR wavelength over 1400nm, their "spectrummatching" is closer than metal halide light sources. Metal halide lamps (Fig. 9b) emit a high quality spectrum distribution up to $900 \mathrm{~nm}$. The spectrum for wavelengths longer than $900 \mathrm{~nm}$ tends to be a mismatch for the solar spectrum in the IR region. For tungsten halogen lamps (Fig. 9c), their low colour temperature is responsible for the mismatch of the output spectrum over 1000nm [222]. Finally, Fig. 9d shows that xenon arc lamps match a broader range of the solar spectrum. This can be improved further by filtering output spectra (i.e. Osram $\mathrm{XBO}^{\circledR}$ theatre lamps) [223].

From these comparisons, an important result is that each light source spectrum, from the same lamp type, varies significantly depending on the manufacturer. For example, some lamp manufacturers filter the output in the UV region, to block UV-B and UV-C radiations which have long term harmful effects on humans [224]. In addition, the data available can be limited as some lamp spectra are measured only over a specific range of wavelengths and for dedicated applications below $2500 \mathrm{~nm}$.

\subsection{Light sources availability, characteristics and requirements}

Additional aspects need to be considered as part of light source selection. Table 4 summarises other significant differences between different light sources including lifetime, additional requirements (e.g. 
required ballast and igniters), internal pressure, average conversion efficiencies ${ }^{5}$ and percentage of popularity ${ }^{6}$.

Table 4 Summary of main characteristics of different light sources

\begin{tabular}{lccccc}
\hline & $\begin{array}{c}\text { Argon } \\
\text { arc lamp }\end{array}$ & $\begin{array}{c}\text { Metal } \\
\text { halide } \\
\text { lamp }\end{array}$ & $\begin{array}{c}\text { Tungsten } \\
\text { halogen } \\
\text { lamp }\end{array}$ & $\begin{array}{c}\text { Xenon } \\
\text { arc } \\
\text { lamp }\end{array}$ & Reference(s) \\
\hline $\begin{array}{l}\text { Life time } \\
\text { (hours) }\end{array}$ & - & $\begin{array}{c}1000- \\
6100\end{array}$ & $35-480$ & $\begin{array}{c}400- \\
3500\end{array}$ & {$[123,211,225-231]$} \\
\hline \multicolumn{7}{l}{$\begin{array}{l}\text { Additional } \\
\text { requirements }\end{array}$} & $\begin{array}{c}\text { SC power } \\
\text { supply, } \\
\text { rectifier } \\
\text { and DC } \\
\text { choke }\end{array}$ & $\begin{array}{c}\text { Ballast } \\
\text { and } \\
\text { igniter }\end{array}$ & - & $\begin{array}{c}\text { Ballast } \\
\text { and } \\
\text { igniter }\end{array}$ & {$[7,39,101,104,117,131,134,148,211]$} \\
\hline $\begin{array}{l}\text { Internal } \\
\text { pressure } \\
\text { (bar) }\end{array}$ & $7-10$ & $10-35$ & - & $10-40$ & {$[6,102-104,112-114,153,154]$} \\
\hline
\end{tabular}

For example, in case of metal halide and xenon arc lamps, ballast and an igniter are required to power the lamp. If one of these elements is incompatible, this may lead to a shift in colour temperature, a dramatically lower lamp life expectancy, and an increased risk of lamp or system failure. Moreover, safety concerns should be evaluated before using certain light sources. For example precautions have to be taken for HID lamps which carry risks associated with retinal damage, UV hazards, or lamp explosion hazards due to their high internal pressures [232,233].

\subsection{Light source and components costs}

A cost comparison of different light sources, and any additional components required, was addressed by selecting the same brand and lamp power. By checking lamp models used in solar simulators (Fig. 9), the Philips brand was found to be used twice with the same input power of $2 \mathrm{~kW}$. The simulator used a metal halide lamp (HPI-T) whereas the second had a tungsten halogen lamp (6994Z). Therefore, a Philips xenon arc lamp with an input power of $2 \mathrm{~kW}$ was selected for comparison (LTIX). However, due to argon arc lamps being unavailable, no data was collected. Cost of lamps and any additional components are listed in Table 5.

Table 5 Cost of different light sources and their requirements (in 2016)

\begin{tabular}{lccccc}
\hline & $\begin{array}{c}\text { Argon arc } \\
\text { lamp }\end{array}$ & $\begin{array}{c}\text { Metal halide } \\
\text { lamp }\end{array}$ & $\begin{array}{c}\text { Tungsten } \\
\text { halogen lamp }\end{array}$ & $\begin{array}{c}\text { Xenon arc } \\
\text { lamp }\end{array}$ & Reference(s) \\
\hline Lamp model & - & $\begin{array}{c}\text { PHILIPS HPI-T } \\
\text { 2000W }\end{array}$ & $\begin{array}{c}\text { PHILIPS 6994Z } \\
\text { 2000W }\end{array}$ & $\begin{array}{c}\text { PHILIPS LTIX- } \\
\text { 2000W/H }\end{array}$ & {$[234-236]$} \\
\hline Lamp cost $(£)$ & - & 96.07 & 32.65 & 634.68 & {$[237-239]$} \\
\hline $\begin{array}{l}\text { Additional } \\
\text { requirements } \\
\text { cost }(£)\end{array}$ & - & 178.20 & 0.00 & 2250 & {$[240-242]$} \\
\hline \begin{tabular}{l} 
Total Cost $(£)$ \\
\hline
\end{tabular} & - & 274.27 & 32.65 & 2884.68 & - \\
\hline
\end{tabular}

5 The average conversion efficiency from electric input power to radiative output power, based on different systems listed in Table 1.

${ }^{6}$ Participation share over the whole period from 1970 to 2016, based on 62 cases listed in Table 1. 
Although costs listed in Table 5 fluctuate with time, power output and suppliers, this cost estimation can be used as an initial criterion in light source selection. According to this data, tungsten halogen lamps are the cheapest light source, while a xenon arc lamp is the most expensive option.

\subsection{Conversion efficiency}

The energy conversion efficiency of a system is defined as the ratio between the useful output and the input [243]. A solar simulator can be considered as a system in which the electrical power supplying the light source is considered as input power, while the useful output power is represented by the radiative power reaching the target area, at which spot is detected. Hence, the energy conversion efficiency of a solar simulator, $\eta_{c}$, can be described by:

$$
\eta_{c}=\text { Total output radiative power/Total electric power consumed by lamps }
$$

By relating this definition to the target area, then it can be rewritten as:

$$
\eta_{c}=\text { Total output flux/(number of lamps } * \text { lamp power/target area) }
$$

The reflector optical efficiency, which is the ratio between the flux reaching the target and the emitted global flux [244], is already embedded in the energy conversion efficiency defined by Eq.(3) and Eq.(4). According to data listed in Table 1, the average conversion efficiencies of different light sources are shown in Table 6.

Table 6 Average conversion efficiency of different light sources

\begin{tabular}{lccccc}
\hline & $\begin{array}{c}\text { Argon } \\
\text { arc lamp }\end{array}$ & $\begin{array}{c}\text { Metal } \\
\text { halide } \\
\text { lamp }\end{array}$ & $\begin{array}{c}\text { Tungsten } \\
\text { halogen lamp }\end{array}$ & $\begin{array}{c}\text { Xenon } \\
\text { arc lamp }\end{array}$ & Reference(s) \\
\hline $\begin{array}{l}\text { Average } \\
\text { conversion } \\
\text { efficiency (\%) }\end{array}$ & 3.08 & 24.59 & 10.21 & 18.77 & $\begin{array}{c}\text { All references listed } \\
\text { in Table 1 }\end{array}$ \\
\hline
\end{tabular}

These values vary from the conversion efficiencies for the individual cases listed in Table 1. This can be attributed to the optical design of different simulators including; reflector designs, optical efficiencies and by using optical filters or transparent obstacles, i.e. lenses or protection glass panels. However, these averaged values can be used as a guideline for an initial estimation of the required electrical power for a specific type of light source.

\section{Conclusions}

A solar simulator device can approximately simulate the sun's radiation by using an artificial light source. In the 1970s, with the development of solar collectors, low-flux solar simulators were principally developed. Twenty years later, high-flux solar simulators were built for testing thermochemical and concentrated solar power components and PV cells. For thermal applications testing, four lamp types have been employed: argon arc, metal halide, tungsten halogen and xenon arc. Since the early 1970s, $37 \%$ and $33 \%$ of solar simulators were built using metal halide and xenon arc lamps respectively. Both 
lamps are HID lamps with a colour temperature (4000-6000K) which is close to that of the sun (5800K). They possess an excellent output spectrum that closely matches that of natural sunlight. A xenon arc lamp has a more stable spectrum as well as a brighter point source, allowing the generation of a high intensity collimated light beam. However, this lamp type has complex and expensive requirements for its power supply, plus filtration requirements for its IR spectrum. Moreover, additional safety precautions have to be considered as its pressure can reach 40 bar during operation, which is five bar higher than the maximum metal halide working pressure. Therefore, metal halides lamps have been used as an alternative in many newly built sun simulators. Additional features have to be considered such conversion efficiency, long-term reliability, cost, additional requirements and life expectancy of each lamp.

\section{Acknowledgment}

This paper is based upon work funded by the Egyptian Government under the Egyptian Government Full External Missions Funding Program. In addition, the "SVC HR-1024i Field Spectroradiometer" was loaned by the NERC Field Spectroscopy Facility, University of Edinburgh, Grant Institute, School of GeoSciences. This equipment was used to measure the output spectrum of the PHILIPS HPI-T and $6994 Z$ lamps used in Cranfield University Solar Laboratory's solar simulator in the Global CSP Laboratory.

\section{REFERENCES}

[1] Halder P, Paul N, Beg M. Assessment of biomass energy resources and related technologies practice in Bangladesh. Renew Sustain Energy Rev 2014;39:444-60.

[2] Masters G. Renewable and Efficient Electric Power Systems. 2nd ed. Wiley; 2013.

[3] Teske S, Sawyer S, Schäfer O, Pregger T, Simon S, Naegler T. Energy [R]evolution: 2015 World Energy Scenario, 5th Edition Report. 2015.

[4] REN21. Renewables 2015 Global Status Report. 2015.

[5] Erbs DG, Klein SA, Duffie JA. Estimation of the diffuse radiation fraction for hourly, daily and monthly-average global radiation. Sol Energy 1982;28:293-302. doi:10.1016/0038092X(82)90302-4.

[6] Wang W. Simulate a "Sun" for Solar Research: A Literature Review of Solar Simulator Technology. Stockholm, Sweden: 2014.

[7] Meng Q, Wang Y, Zhang L. Irradiance characteristics and optimization design of a large-scale solar simulator. Sol Energy 2011;85:1758-67. doi:10.1016/j.solener.2011.04.014.

[8] Hollingsworth R. A Survey of Large Space Chambers. Washington: 1963.

[9] Eddy R. Design and Construction of the 15-ft-Beam Solar Simulator SS15B. Technical Report 32-1274: 1968.

[10] Barnett R, Thiele C. JPL Advanced Solar Simulator Design Type A. JPT Technical Memorandum No.33-141: 1963

[11] Namin A, Jivacate C, Chenvidhya D, Kirtikara K, Thongpron J. Construction of tungsten halogen, 
pulsed LED, and combined tungsten halogen-LED solar simulators for solar cellcharacterization and electrical parameters determination. Int J Photoenergy 2012;2012:1-9.

[12] Zaini H, Yoo J-K, Park S, Lee D-H. Indoor calibration method for UV index meters with a solar simulator and a reference spectroradiometer. Int J Metrol Qual Eng 2016;7:101. doi:10.1051/ijmqe/2015031.

[13] Kolberg D, Schubert F, Lontke N, Zwigart A, Spinner DM. Development of tunable close match LED solar simulator with extended spectral range to UV and IR. Energy Procedia 2011;8:100-5. doi:10.1016/j.egypro.2011.06.109.

[14] Böhm M, Scheer HC, Wagemann H-G. Solar simulator measurement system for large-area solar cells at standard test conditions. Energy Convers Manag 1985;25:105-13.

[15] Martinez A, Roberts G, Garzarella K, Lutz M, Caswell M. Interoperability of 300 watt and 150 watt xenon arc solar simulators in sun protection factor and in UVA protection factor clinical testing. Photodermatol Photoimmunol Photomed 2013;29:79-83.

[16] Sayre R, Dowdy J. Examination of Solar Simulators Used for the Determination of Sunscreen UVA Efficacy. Photochem Photobiol 2010;86:162-7. doi:10.1111/j.1751-1097.2009.00633.x.

[17] Moyal D, Verschoore $M$, Binet $O$. Indoor simulation of polymorphic light eruption using a UVA/UVB solar simulator and prevention by a well-balanced UVA/UVB sunscreen. J Dermatolog Treat 1999;10:255-9.

[18] Jake Richardson. \$2.5 Million Raised By Solar Simulator Startup 2014. http://solarlove.org/2-5million-raised-solar-simulator-startup/ (accessed November 9, 2016).

[19] Suntech Group AB. Solar Simulation Technology 2016. http://suntechgroup.se/sunlightsimulation/ (accessed November 9, 2016).

[20] Eternal Sun B.V. Automotive industry 2016. http://www.eternalsun.com/industries/automotiveindustry/ (accessed November 9, 2016).

[21] Xiong Z, Walsh TM, Aberle AG. PV module durability testing under high voltage biased damp heat conditions. Energy Procedia 2011;8:384-9. doi:10.1016/j.egypro.2011.06.154.

[22] Cotfas DT, Cotfas P., Floroian D, Floroian L, Cernat M. Ageing of photovoltaic cells under Concentrated Light. 2015 Intl Aegean Conf. Electr. Mach. Power Electron. (ACEMP), 2015 Intl Conf. Optim. Electr. Electron. Equip. 2015 Intl Symp. Adv. Electromechanical Motion Syst., Side, Turkey: IEEE; 2015, p. 599-604. doi:10.1109/OPTIM.2015.7427048.

[23] Ihara T, Jelle BP, Gao T, Gustavsen A. Accelerated aging of treated aluminum for use as a cool colored material for facades. Energy Build 2016;112:184-97. doi:10.1016/j.enbuild.2015.12.014.

[24] Siddiqui R, Kumar R, Jha GK, Gowri G, Morampudi M, Rajput P, et al. Comparison of different technologies for solar PV (Photovoltaic) outdoor performance using indoor accelerated aging tests for long term reliability. Energy 2016;107:550-61. doi:10.1016/j.energy.2016.04.054.

[25] Mohsenpour SF, Richards B, Willoughby N. Spectral conversion of light for enhanced microalgae growth rates and photosynthetic pigment production. Bioresour Technol 2012;125:75-81. doi:10.1016/j.biortech.2012.08.072.

[26] Seo YH, Lee Y, Jeon DY, Han J-I. Enhancing the light utilization efficiency of microalgae using organic dyes. Bioresour Technol 2015;181:355-9. doi:10.1016/j.biortech.2015.01.031.

[27] Seo YH, Cho C, Lee J-Y, Han J-I. Enhancement of growth and lipid production from microalgae using fluorescent paint under the solar radiation. Bioresour Technol 2014;173:193-7. doi:10.1016/j.biortech.2014.09.012. 
[28] Conte LO, Schenone A V., Alfano OM. Photo-Fenton degradation of the herbicide 2,4-D in aqueous medium at $\mathrm{pH}$ conditions close to neutrality. J Environ Manage 2016;170:60-9. doi:10.1016/j.jenvman.2016.01.002.

[29] Yokota O, Oku Y, Sano T, Hasegawa N, Matsunami J, Tsuji M, et al. Stoichiometric consideration of steam reforming of methane on Ni/Al2O3 catalyst at $650^{\circ} \mathrm{C}$ by using a solar furnace simulator. Int J Hydrogen Energy 2000;25:81-6. doi:10.1016/S0360-3199(99)00011-7.

[30] Lédé J, Boutin O, Elorza-Ricart E, Ferrer M, Mollard F. Production of Zinc from the Reduction of $\mathrm{ZnO}$ in the Presence of Cellulose in a Solar Simulator. J Sol Energy Eng 2001;123:102-8. doi:10.1115/1.1352738.

[31] Beghi G. Performance of Solar Energy Converters: Thermal Collectors and Photovoltaic Cells. Dordrecht, Holland: D. Reidel Publishing Company; 1983. doi:10.1007/978-94-011-9813-4.

[32] Mei L, Infield DG, Gottschalg R, Loveday DL, Davies D, Berry M. Equilibrium thermal characteristics of a building integrated photovoltaic tiled roof. Sol Energy 2009;83:1893-901. doi:10.1016/j.solener.2009.07.002.

[33] Sarwar J, Georgakis G, LaChance R, Ozalp N. Description and characterization of an adjustable flux solar simulator for solar thermal, thermochemical and photovoltaic applications. Sol Energy 2014;100:179-94. doi:10.1016/j.solener.2013.12.008.

[34] Chow S, Valdivia CE, Wheeldon JF, Ares R, Arenas OJ, Aimez V, et al. Thermal test and simulation of alumina receiver with high efficiency multi-junction solar cell for concentrator systems. In: Schriemer HP, Kleiman RN, editors. Photonics North 2010, vol. 7750, Niagara Falls, Canada: SPIE; 2010, p. 775035. doi:10.1117/12.872894.

[35] Andreev VM, Vlasov AS, Khvostikov VP, Khvostikova OA, Gazaryan PY, Sadchikov NA, et al. Solar Thermophotovoltaic Converter with Fresnel Lens and GaSb Cells. 2006 IEEE 4th World Conf. Photovolt. Energy Conf., vol. 1, Waikoloa, HI: IEEE; 2006, p. 644-7. doi:10.1109/WCPEC.2006.279537.

[36] Luque A, Hegedus S. Handbook of Photovoltaic Science and Engineering. 2nd ed. John Wiley \& Sons, Ltd; 2011. doi:10.1017/CBO9781107415324.004.

[37] McEvoy A, Markvart T. Practical Handbook of Photovoltaics: Fundamentals and Applications. 2nd ed. Academic Press; 2011.

[38] Pérez-Higueras P, Fernández EF. High Concentrator Photovoltaics: Fundamentals, Engineering and Power Plants. Springer, Switzerland; 2015.

[39] Codd DS, Carlson A, Rees J, Slocum AH. A low cost high flux solar simulator. Sol Energy 2010;84:2202-12. doi:10.1016/j.solener.2010.08.007.

[40] Vaan R De. Artificial light source for solar simulation. In: Commission TE, Aranovich E, Gillett B, editors. Work. Sol. Simulators, Ispra, Italy: Commission of the European Communities Joint Research Centre Ispra Establishment; 1982, p. 75-82.

[41] Saunders P. Radiation Thermometry Principles. Radiat. Thermom. Fundam. Appl. Petrochemical Ind., SPIE; 2007, p. 5-22. doi:10.1117/3.741687.

[42] Boreman GD. Sources of Radiation. Basic Electro-Optics Electr. Eng., Bellingham, WA, USA: SPIE; 1998, p. 47-53. doi:10.1117/3.294180.

[43] Holmberg J, Flynn C, Portinari L. The colours of the Sun. Mon Not R Astron Soc 2006;367:44953. doi:10.1111/j.1365-2966.2005.09832.x.

[44] Shu FH. The Physical Universe: An Introduction to Astronomy. University Science Books; 1982. 
[45] Cicerone RJ. Human forcing of climate change: Easing up on the gas pedal. Proc. Natl. Acad. Sci., vol. 97, 2000, p. 10304-6. doi:10.1073/pnas.97.19.10304.

[46] Hu Y, Ding F. Radiative constraints on the habitability of exoplanets Gliese $581 \mathrm{c}$ and Gliese 581 d. Astron. Astrophys., vol. 526, 2011, p. 1-8. doi:10.1051/0004-6361/201014880.

[47] Mann A. System Considerations. Infrared Opt. Zoom Lenses, Bellingham, WA, USA: SPIE; 2009, p. 1-12. doi:10.1117/3.829008.ch1.

[48] Holweger H. Damping and Solar Abundance of Sodium from Nal Fraunhofer Lines. Astron Astrophys 1971;10:128-33.

[49] Chance K V., Spurr RJD. Ring effect studies: Rayleigh scattering, including molecular parameters for rotational Raman scattering, and the Fraunhofer spectrum. Appl Opt 1997;36:5224-30. doi:10.1364/AO.36.005224.

[50] Gates DM. Spectral Distribution of Solar Radiation at the Earth's Surface. Science (80- ) 1966;151:523-9. doi:10.1126/science.151.3710.523.

[51] Kwok S. Physics and Chemistry of the Interstellar Medium: Chemistry, Chemistry. 1st ed. Content Technologies, Inc.; 2016.

[52] Wurfel P. Physics of Solar Cells: From Basic Principles to Advanced Concepts. 2nd ed. Wiley$\mathrm{VCH} ; 2009$.

[53] Kasten F. A New Table and Approximation Formula for the Relative Optical Air Mass. Theor Appl Climatol 1965;14:206-23.

[54] Kasten F, Young AT. Revised optical air mass tables and approximation formula. Appl Opt 1989;28:4735-8.

[55] Grenier JC, Casinière AD La, Cabot T. A spectral model of Linke's turbidity factor and its experimental implications. Sol Energy 1994;52:303-13.

[56] Agrawal B, Tiwari GN. Solar Radiation and its Availability on Earth. Build. Integr. Photovolt. Therm. Syst. Sustain. Dev., Royal Society of Chemistry; 2010, p. 1-49.

[57] Malhotra B. Plasmonic Enhancement of Silicon Solar Cells with Metal Nanoparticles. North Carolina State University, 2011. doi:10.1017/CBO9781107415324.004.

[58] Neckel H, Labs D. Improved Data of Solar Spectral Irradiance from 0.33 to $1.25 \mathrm{um}$. Sol Phys 1981;74:231-49.

[59] Shanmugam P, Ahn YH. Reference solar irradiance spectra and consequences of their disparities in remote sensing of the ocean colour. Ann Geophys 2007;25:1235-52. doi:10.5194/angeo-25-1235-2007.

[60] ASTM Standard E490. Standard Solar Constant and Zero Air Mass Solar Spectral Irradiance Tables. West Conshohocken, Pennsylvania: 2000.

[61] 2011 ASHRAE Handbook - Heating, Ventilating, and Air-Conditioning Applications. I-P Ed. American Society of Heating, Refrigerating and Air-Conditioning Engineers, Inc.; 2011.

[62] Rhodes FHT, Stone RO. Language of the Earth. Pergamon Press Inc.; 1981.

[63] Gonzalez C, Ross R. Performance measurement reference conditions for terrestrial photovoltaics. Proc. Int. Sol. Energy Soc. Conf., Phoenix, AZ: 1980, p. 1-5.

[64] Gueymard CA, Myers D, Emery K. Proposed reference irradiance spectra for solar energy systems testing. Sol Energy 2002;73:443-67. doi:10.1016/S0038-092X(03)00005-7. 
[65] Bird RE, Hulstrom RL, Lewis LJ. Terrestrial Solar Spectral Data Sets. Sol Energy 1983;30:56373.

[66] ASTM Standard G173-03. Standard Tables for Reference Solar Spectral Irradiances: Direct Normal and Hemispherical on $37^{\circ}$ Tilted Surface. West Conshohocken, Pennsylvania: 2012.

[67] ASTM Standard G159-98. Standard Tables for References Solar Spectral Irradiance at Air Mass 1.5: Direct Normal and Hemispherical for a $37^{\circ}$ Tilted Surface (Withdrawn 2005). West Conshohocken, Pennsylvania: 1998.

[68] Farage MA, Miller KW, Maibach HI. Textbook of Aging Skin. 2010 Ed. Springer Berlin Heidelberg; 2010.

[69] McKenzie R, Blumthaler M, Diaz S, Fioletov V, Herman J, Seckmeyer G, et al. Rationalizing Nomenclature for UV Doses and Effects on Humans: Joint publication of CIE and WMO (World Meteorological Organization). Vienna, AUSTRIA: 2014.

[70] CIE Standard S 017/E:2011. International Lighting Vocabulary. Vienna, Austria: 2011.

[71] Masters GM. Renewable and Efficient Electric Power Systems. 2nd ed. Wiley-Blackwell; 2013.

[72] Krusi P, Schmid R. The CSI lamp as a source of radiation for solar simulation. Sol Energy 1983;30:455-62. doi:10.1177/096032717801000307.

[73] Luque A, Hegedus S. Handbook of Photovoltaic Science and Engineering. 2nd Ed. WileyBlackwell; 2010.

[74] Green MA. Solar Cell operating Priciples, Technology and System Applications. N.Y., USA: Prentice Hall Inc.; 1982.

[75] Herrero R, Victoria M, Domínguez C, Askins S, Antón I, Sala G. Concentration photovoltaic optical system irradiance distribution measurements and its effect on multi-junction solar cells. Prog Photovoltaics Res Appl 2012;20:423-30. doi:10.1002/pip.1145.

[76] Van WGJHM, Meijerink A, Schropp REI. Solar Spectrum Conversion for Photovoltaics Using Nanoparticles. Third Gener. Photovoltaics, InTech; 2012. doi:10.5772/39213.

[77] Agbo SN, Merdzhanova T, Rau U, Astakhov O. Illumination intensity and spectrum-dependent performance of thin-film silicon single and multijunction solar cells. Sol Energy Mater Sol Cells 2017;159:427-34. doi:10.1016/j.solmat.2016.09.039.

[78] Sopori BL. Apparatus for synthesis of a solar spectrum. US5217285, 1993.

[79] Sopori BL, Marshall C, Emery K. Mixing optical beams for solar simulation-a new approach (to solar cell testing). IEEE Conf. Photovolt. Spec., IEEE; 1990, p. 1116-21. doi:10.1109/PVSC.1990.111790.

[80] Warner JH, Walters RJ, Messenger SR, Lorentzen JR, Summers GP, Cotal HL, et al. Measurement and characterization of triple junction solar cells using a close matched multizone solar simulator. In: Kafafi ZH, Lane PA, editors. Proc. SPIE - Org. Photovoltaics V, vol. 5520, Bellingham, WA, USA: International Society for Optics and Photonics; 2004, p. 45. doi:10.1117/12.559734.

[81] Namin A, Jivacate C, Chenvidhya D, Kirtikara K, Thongpron J. Determination of solar cell electrical parameters and resistances using color and white LED-based solar simulators with high amplitude pulse input voltages. Renew Energy 2013;54:131-7. doi:10.1016/j.renene.2012.08.046.

[82] Linden KJ, Neal WR, Serreze HB. Adjustable spectrum LED solar simulator. In: Streubel KP, Jeon H, Tu L-W, Strassburg M, editors. Proc. SPIE - Light. Diodes Mater. Devices, Appl. Solid 
State Light. XVIII, vol. 9003, San Francisco, CA, USA: International Society for Optics and Photonics; 2014, p. 900317. doi:10.1117/12.2035649.

[83] Nakamura T, Imaizumi M, Sato S, Ohshima T. Estimation of subcell photocurrent in IMM3J using LED bias light. 2013 IEEE 39th Photovolt. Spec. Conf., Tampa, FL, USA: IEEE; 2013, p. 0696700. doi:10.1109/PVSC.2013.6744247.

[84] IEC 60904-9. Photovoltaic devices - Part 9: Solar simulator performance requirements. Geneva: IEC (International Electrotechnical Commission); 2007.

[85] ASTM Standard E927. Standard Specification for Solar Simulation for Photovoltaic Testing. West Conshohocken, Pennsylvania: 2015.

[86] ASTM Standard E948. Standard Test Method for Electrical Performance of Photovoltaic Cells Using Reference Cells Under Simulated Sunlight. West Conshohocken, Pennsylvania: 2015. doi:10.1520/E0948-15.2.

[87] ASTM Standard E1036. Standard Test Methods for Electrical Performance of Nonconcentrator Terrestrial Photovoltaic Modules and Arrays Using Reference Cells. West Conshohocken, Pennsylvania: 2015. doi:10.1520/E1036-08.2.

[88] ASTM Standard E1362. Standard Test Methods for Calibration of Non-Concentrator Photovoltaic Non-Primary Reference Cells. West Conshohocken, Pennsylvania: 2015. doi:10.1520/E136215.1.6.

[89] JIS C 8912. Solar simulators for crystalline solar cells and modules. 2010.

[90] EN 60904-9. Photovoltaic devices - Solar simulator performance requirements. British Standards Institute; 2008.

[91] Neumann A, Groer U. Experimenting with concentrated sunlight using the DLR solar furnace. Sol Energy 1996;58:181-90. doi:10.1016/S0038-092X(96)00079-5.

[92] Xu X-Y. Applied Research of Quantum Information Based on Linear Optics. 1st Ed. SpringerVerlag Berlin Heidelberg; 2016. doi:10.1007/978-3-662-49804-0.

[93] Ashcroft NW. Solid State Physics. 1st Ed. Content Technologies, Inc.; 2016.

[94] Smith J. Organic Chemistry. 4th Ed. Content Technologies, Inc.; 2016.

[95] ISO 9806. Solar energy. Solar thermal collectors. Test methods. British Standards Institute; 2013.

[96] ISO 19467. Thermal performance of windows and doors - Determination of solar heat gain coefficient using solar simulator. British Standards Institute; 2016.

[97] EN 12975-1. Thermal solar systems and components - Solar collectors - Part 1: General requirements. British Standards Institute; 2006.

[98] EN 12975-2. Thermal solar systems and components - Solar collectors - Part 2: Test methods. British Standards Institute; 2006.

[99] EN 12976-1. Thermal solar systems and components - Factory made systems - Part 1: General requirements. British Standards Institute; 2017.

[100] EN 12976-2. Thermal solar systems and components - Factory made systems — Part 2: Test methods. British Standards Institute; 2006.

[101] Curtis HB, Decker AJ. Electrical characteristics of a free-burning direct-current argon arc operating between 90 and 563 kilowatts with two types of cathodes. NASA-TN-D-8032: 1975. 
[102] Halliop B. A Dynamic Model of a High Temperature Arc Lamp. University of Toronto, 2008.

[103] Decker AJ, Pollack JL. A 400 Kilowatt Argon Arc Lamp for Solar Simulation. 6th Sp. Simul. Conf., New York: 1972, p. 1-21.

[104] Yan W, Dawson FP. Power supply design considerations for maintaining a minimum sustaining current in a vortex water wall high-pressure argon arc lamp. IEEE Trans Ind Appl 1998;34:101525. doi:10.1109/28.720441.

[105] Camm DM, Kjorvel A, Housden AJ, Halpin NP, Parfeniuk DA, Frenz AJ. High intensity radiation apparatus and fluid recirculating system therefor. US4937490 A, 1990.

[106] Grover HS, Dawson FP, Camm DM, Cressault Y, Lieberer M. Modelling of a Vortex Water-Wall Argon Arc Lamp for Rapid Thermal Annealing Applications. IEEE Trans Ind Appl 2015;51:481723. doi:10.1109/TIA.2015.2451099.

[107] Vortek Industries Ltd. Model 201-200/200 200 kW Arc Lamp System. Vancouver BC, V6P 6T7 Canada: 1999.

[108] Pullen H, Albach G, Harrison S. The solar simulator at the Canadian National Solar Test Facility. In: Commission TE, Aranovich E, Gillett B, editors. Work. Sol. Simulators, Ispra, Italy: Commission of the European Communities Joint Research Centre Ispra Establishment; 1982, p. 70-4.

[109] Richards D, Albach G. A large area solar simulator construction and performance. In: Commission TE, Aranovich E, Gillett B, editors. Work. Sol. Simulators, Ispra, Italy: Commission of the European Communities Joint Research Centre Ispra Establishment; 1982, p. 3-10.

[110] Hirsch D, Zedtwitz P V., Osinga T, Kinamore J, Steinfeld A. A New 75 kW High-Flux Solar Simulator for High-Temperature Thermal and Thermochemical Research. J Sol Energy Eng 2003;125:117. doi:10.1115/1.1528922.

[111] Barnes NP, Remelius DK. Argon arc lamps. Appl Opt 1985;24:1947-9.

[112] Grondzik WT, Kwok AG, Stein B, Reynolds JS. Mechanical and Electrical Equipment for Buildings. Wiley; 2009.

[113] Dinklage A, Klinger T, Marx G. Plasma Physics: Confinement, Transport and Collective Effects. 2005 Ed. Springer; 2005.

[114] Osram. Metal Halide Lamps Photo Optics: Technology and Application. Osram Sylvania Inc.; 2000.

[115] Waymouth JF. Electric Discharge Lamps (Monographs in Modern Electrical Technology). The MIT Press; 1971.

[116] Osram. The operation principle: Generating light through gas discharge 2016. http://www.osram.com/osram_com/news-and-knowledge/high-pressure-dischargelamps/professional-knowledge/operating-principle-high-pressure-discharge/index.jsp (accessed March 22, 2016).

[117] Osram. HMI 1800W/SE XS 2016. https://www.technilux.com/files/documents/bulbs/LHMI1800W-SE-O_spec-sheet.pdf (accessed November 9, 2016).

[118] Ley W. Survey of Solar Simulator Test Facilities and Initial Results of IEA Round Robin Tests Using Solar Simulators. DFVLR, Cologne: 1979.

[119] Ouden $C$ den, Wijsman AJTM. Lamp array design and simulator chamber design of the TNOSolar-Simulator. In: Commission TE, Aranovich E, Gillett B, editors. Work. Sol. Simulators, Ispra, 
Italy: Commission of the European Communities Joint Research Centre Ispra Establishment; 1982, p. 62-5.

[120] Dokos W. Presentation of some U.S. solar simulator characteristics. In: Commission TE, Aranovich E, Gillett B, editors. Work. Sol. Simulators, Ispra; Italy: 1982, p. 51-61.

[121] Gene A. Zerlaut, William T. Dokos, William J. Putman RKS. Solar simulator and method. US4423469, 1983.

[122] Higashi, T., Umezit S. The conceptual design of a solar simulator for evaluating collectors. In: Commission TE, Aranovich E, Gillett B, editors. Work. Sol. Simulators, Ispra; Italy: Commission of the European Communities Joint Research Centre Ispra Establishment; 1982, p. 36-9.

[123] Leiner W, Altfeld K. Design of a solar simulator with reduced thermal radiation to be used as a component of a test facility for air heating collectors. In: Commission TE, Aranovich E, Gillett B, editors. Work. Sol. Simulators, Ispra, Italy: Commission of the European Communities Joint Research Centre Ispra Establishment; 1982, p. 88-97.

[124] Kenny SP. Design of an indoor solar simulator. Colorado State University, Fort Collins,. CO., 1993.

[125] Kenny SP, Davidson JH. Design of a Multiple-Lamp Large-Scale Solar Simulator. J Sol Energy Eng 1994;116:200-5.

[126] Geisheker, P.J.; Putman, W.J.; Bard LA. Development of facilities and methods for thermal performance tests of passive domestic hot water systems. 6th Natl. Passiv. Sol. Conf., Portland, OR, USA: 1981.

[127] Gillett WB. Performance Test Procedures for Thermal Collectors (2) Solar Simulators. In: Beghi G, editor. Perform. Sol. Energy Convert. Therm. Collect. Photovolt. Cells, Springer Netherlands; 1983, p. 125-46.

[128] Brinkworth BJ. Results of solar heating experiments. Philos Trans R Soc London A Math Phys Eng Sci 1980;295:361-73.

[129] Gillet WB. Solar simulators and indoor testing. Test. Sol. Collect. Syst. Proc. Conf. Sic. R. Inst., London: International Solar Energy Society, UK Section; 1977, p. 30-48.

[130] Krusi P, Schmid R. Design of an inexpensive solar simulator. Sun II; Proc. Silver Jubil. Congr., Atlanta, Ga: 1979, p. 417-21.

[131] Codd DS. Concentrated Solar Power on Demand by. Massachusetts Institute of Technology, 2011.

[132] Madsen MV. Lengthening the lifetime of roll-to-roll produced polymer solar cells. Technical University of Denmark, 2013.

[133] Atlas Material Testing Technology. Network of Weathering Products \& Services. 2011.

[134] Dong X, Nathan GJ, Sun Z, Gu D, Ashman PJ. Concentric multilayer model of the arc in high intensity discharge lamps for solar simulators with experimental validation. Sol Energy 2015;122:293-306. doi:10.1016/j.solener.2015.09.004.

[135] Ekman BM, Brooks G, Akbar Rhamdhani M. Development of high flux solar simulators for solar thermal research. Sol Energy Mater Sol Cells 2015;141:436-46. doi:10.1016/j.solmat.2015.06.016.

[136] Pernpeintner J, Happich C, Lüpfert E, Schiricke B, Lichtenthäler N, Weinhausen J. Linear Focus Solar Simulator Test Bench for Non-destructive Optical Efficiency Testing of Parabolic Trough Receivers. Energy Procedia 2015;69:518-22. doi:10.1016/j.egypro.2015.03.060. 
[137] Ametek. Introduction to Atlas SolarConstant Series 4000 watt Sun Sources 2016. http://www.lasermotion.com/atlassun.html\#atlas1 (accessed November 9, 2016).

[138] Hill JC, Dolenga A. Fluorine-cycle incandescent lamps. J Appl Phys 1977;48:3089-92. doi:10.1063/1.324079.

[139] Yoshizawa T. Handbook of Optical Metrology: Principles and Applications. vol. 2. 2nd ed. CRC Press; 2015.

[140] Osram. Product datasheet: Low-voltage halogen lamps without reflector 2016:1-3. http://www.osram.com/osram_com/products/lamps/specialty-lamps/low-voltage-halogenlamps/low-voltage-halogen-lamps-without-reflector/index.jsp?productld=ZMP_1006707 (accessed November 9, 2016).

[141] Bommel W van. Halogen Lamp. Encycl Color Sci Technol 2014:1-9. doi:10.1007/978-3-64227851-8_126-8.

[142] Bickler D. The simulation of solar radiation. Sol Energy 1962;6:64-8.

[143] Howell JR, Menguc MP, Siegel R. Thermal Radiation Heat Transfer. 6th ed. CRC Press; 2015.

[144] Yass K, Curtis HB. Low cost air mass 2 solar simulator. NASA TM X-3059: 1974.

[145] Yass K, Curtis HB. Operational performance of a low-cost air mass 2 solar simulator. NASA TMX-71162: 1975.

[146] Simon F. Flat plate solar collector performance evaluation with a solar simulator as a basis for collector selection and performance prediction. Sol Energy 1976;18:451-66.

[147] Humphries W, George C. Use of the Marshall Space Flight Center solar simulator in collector performance evaluation. NASA-TM-78165: 1978.

[148] Rueb IRA. Quartz halogen dichroic mirror lamps for solar simulation. In: Commission TE, Aranovich E, Gillett B, editors. Work. Sol. Simulators, Ispra, Italy: Commission of the European Communities Joint Research Centre Ispra Establishment; 1982, p. 20-35.

[149] Garg HP, Shukla AR, Madhuri I, Agnihotri RC, Chakravertty S. Development of a simple lowcost solar simulator for indoor collector testing. Appl Energy 1985;21:43-54. doi:10.1016/03062619(85)90073-X.

[150] Turner TL, Ash RL. Numerical and Experimental Analyses of the Radiant Heat Flux Produced by Quartz Heating Systems 1994:41.

[151] Shatat M, Riffat S, Agyenim F. Experimental testing method for solar light simulator with an attached evacuated solar collector. Int J Energy Environ 2013;4:219-30.

[152] Beeson EJG. The CSI lamp as a source of radiation for solar simulation. Light Reseach Technol 1978;10:164-6.

[153] Skoog DA. Principles of Instrumental Analysis. 6th ed. Content Technologies, Inc.; 2015.

[154] Pedrotti FL, Pedrotti L. Introduction to Optics. 3rd ed. Content Technologies, Inc.; 2016.

[155] Osram. XBO HPN Xenon short-arc lamps for digital cinema projection 2016. https://www.osram.com/osram_com/products/lamps/specialty-lamps/xbo/xbo-hpn/index.jsp (accessed November 9, 2016).

[156] Martini M. Principles of Light Sources for Lithography 2014. http://www.martinitech.com/tag/light-sources/ (accessed November 9, 2016). 
[157] Ahmadi H. HV Igniter 2015. http://www.ece.ubc.ca/ hameda/igniter_for_xenon_shortarc_lamp.htm (accessed November 9, 2016).

[158] Kuhn P, Hunt A. A new solar simulator to study high temperature solid-state reactions with highly concentrated radiation. Sol Energy Mater 1991;24:742-50.

[159] Kochan HW, Huebner WF, Sears DWG. Simulation Experiments with Cometary Analogous Material. Lab. Astrophys. Sp. Res., Springer Netherlands; 1999, p. 623-65.

[160] Jaworske DA, Jefferies KS, Mason LS. Alignment and Initial Operation of an Advanced Solar Simulator 1996;33:867-9. doi:doi:10.2514/6.1996-102.

[161] Dibowski H-G. High-Flux Solar Furnace and Xenon-High-Flux Solar Simulator 2014. http://www.dlr.de/sf/en/desktopdefault.aspx/tabid-8558/14717_read-28267/ (accessed February $25,2016)$.

[162] Alxneit I, Dibowski G, Facilities S. Solar Simulator Evaluation Report. Project SFERA, PSI and DLR: 2011.

[163] Petrasch J, Steinfeld A. A Novel High-Flux Solar Simulator Based on an Array of Xenon Arc Lamps: Optimization of the Ellipsoidal Reflector and Optical Configuration. ASME 2005 Int. Sol. Energy Conf., Orlando, Florida: 2005, p. 175-80.

[164] Petrasch J, Coray P, Meier A, Brack M, Häberling P, Wuillemin D, et al. A Novel 50 kW 11,000 suns High-Flux Solar Simulator Based on an Array of Xenon Arc Lamps. J Sol Energy Eng 2007;129:405. doi:10.1115/1.2769701.

[165] Craig RA. Investigating the use of Concentrated Solar Energy to Thermally Decompose Limestone. The University of Adelaide, 2010.

[166] Krueger KR, Davidson JH, Lipiński W. Design of a New 45 kWe High-Flux Solar Simulator for High-Temperature Solar Thermal and Thermo-Chemical Research. J Sol Energy Eng 2011;133:0110131-8.

[167] Krueger KR. Design and Characterization of a Concentrating Solar Simulator. The University of Minnesota, 2012.

[168] Krueger KR, Lipiński W, Davidson JH, Lip, Davidson JH. Operational Performance of the University of Minnesota 45kWe High-flux Solar Simulator. J Sol Energy Eng 2013;135:44501-1044501-4. doi:10.1115/ES2012-91119.

[169] Li Z, Tang D, Du J, Li T. Study on the radiation flux and temperature distributions of the concentrator-receiver system in a solar dish/Stirling power facility. Appl Therm Eng 2011;31:1780-9. doi:10.1016/j.applthermaleng.2011.02.023.

[170] Erickson BM. Characterization of the University of Florida Solar Simulator and an Inverse Solution for Identifying Intensity Distributions from Multiple Flux Maps in Concentrating Solar Applications. University of Florida, 2012. doi:10.1017/CBO9781107415324.004.

[171] Wang W, Aichmayer L, Laumert B, Fransson T. Design and validation of a low-cost high-flux solar simulator using Fresnel lens concentrators. Energy Procedia 2014;49:2221-30. doi:10.1016/j.egypro.2014.03.235.

[172] Li J, Gonzalez-Aguilar J, Pérez-Rábago C, Zeaiter H, Romero M. Optical Analysis of a Hexagonal 42kWe High-flux Solar Simulator. Energy Procedia 2014;57:590-6. doi:10.1016/j.egypro.2014.10.213.

[173] Li J, Gonzalez-Aguilar J, Romero M. Line-concentrating Flux Analysis of 42kWe High-flux Solar Simulator. Energy Procedia 2015;69:132-7. doi:10.1016/j.egypro.2015.03.016. 
[174] Okuhara Y, Kuroyama T, Tsutsui T, Noritake K, Aoshima T. A Solar Simulator for the Measurement of Heat Collection Efficiency of Parabolic Trough Receivers. Energy Procedia 2015;69:1911-20. doi:10.1016/j.egypro.2015.03.185.

[175] Wang W. Development of an Impinging Receiver for Solar Dish-Brayton Systems. Royal Institute of Technology, 2015.

[176] Matson R, Emery KA, Bird RE. Terrestrial solar spectra, solar simulation and solar cell shortcircuit current calibration: A review. Sol Cells 1984;11:105-45. doi:10.1016/03796787(84)90022-X.

[177] Ma Y, Peng S, Long X, Fu X, Cao Q, Yang B, et al. Influencing factors of life of high power linear xenon-filled flash lamp. Qiangjiguang Yu Lizishu/High Power Laser Part Beams 2010;22:24836. doi:10.3788/HPLPB20102210.2483.

[178] Health and Safety Executive. Ozone : Health hazards and control measures. 2014.

[179] Choi Y, Nguyen D, Tabibi B, Lee J. Installation and preliminary operation of a solar thermalelectric propulsion system. 27th Plasma Dyn. Lasers Conf., New Orleans, USA: American Institute of Aeronautics and Astronautics; 1996, p. 1-9. doi:10.2514/6.1996-2321.

[180] Nguyen D, Nam M, Tabibi B, Lee J, Nguyen D, Nam M, et al. Performance of thermal plume in solar thermal-electric propulsion system. 33rd Jt. Propuls. Conf. Exhib., Seattle, USA: American Institute of Aeronautics and Astronautics; 1997, p. 1-6. doi:10.2514/6.1997-3207.

[181] Osinga T, Frommherz U, Steinfeld A, Wieckert C. Experimental Investigation of the Solar Carbothermic Reduction of $\mathrm{ZnO}$ Using a Two-cavity Solar Reactor. J Sol Energy Eng 2004;126:633. doi:10.1115/1.1639001.

[182] Mondol JD, Smyth M, Zacharopoulos A, O'Brien V. Experimental evaluation of a novel heat exchanger for solar water heating systems. ISES Sol. World Congr. 2009 Renew. Energy Shap. Our Futur., 2009, p. 499-507.

[183] Zacharopoulos A, Mondol JD, Smyth M, Hyde T, O'Brien V. State-of-the-art solar simulator with dimming control and flexible mounting. 29th ISES Bienn. Sol. World Congr. 2009, ISES 2009, Johannesburg; South Africa: 2009, p. 854-63.

[184] Kim S in, Kissick J, Spence S, Boyle C. Design, analysis and performance of a polymer-carbon nanotubes based economic solar collector. Sol Energy 2016;134:251-63. doi:10.1016/j.solener.2016.04.019.

[185] Guo P, Wang Y, Meng Q, Li J. Experimental study on an indoor scale solar chimney setup in an artificial environment simulation laboratory. Appl Therm Eng 2016;107:818-26. doi:10.1016/j.applthermaleng.2016.07.025.

[186] Sabahi H, Tofigh AA, Kakhki IM, Bungypoor-Fard H. Design, construction and performance test of an efficient large-scale solar simulator for investigation of solar thermal collectors. Sustain Energy Technol Assessments 2016;15:35-41. doi:10.1016/j.seta.2016.03.004.

[187] Sopian K, Supranto, Daud WRW, Othman MY, Yatim. B. Technical note: Thermal performance of the double-pass solar collector with and without porous media. Renew Energy 1999;18:55764.

[188] Velmurugan P, Kalaivanan R. Energy and exergy analysis in double-pass solar air heater. Sadhana 2016;41:369-76. doi:10.1007/s12046-015-0456-5.

[189] Kongtragool B, Wongwises S. A four power-piston low-temperature differential Stirling engine using simulated solar energy as a heat source. Sol Energy 2008;82:493-500. doi:10.1016/j.solener.2007.12.005. 
[190] Kongtragool B, Wongwises S. Performance of a twin power piston low temperature differential Stirling engine powered by a solar simulator. Sol Energy 2007;81:884-95. doi:10.1016/j.solener.2006.11.004.

[191] Njie DN, Rumsey TR. Influence of process conditions on the drying rate of cassava chips in a solar simulator. Dry Technol 1998;16:181-98. doi:10.1080/07373939808917398.

[192] Mink G, Horváth L, Evseev EG, Kudish Al. Design parameters, performance testing and analysis of a double-glazed, air-blown solar still with thermal energy recycle. Sol Energy 1998;64:26577. doi:10.1016/S0038-092X(98)00076-0.

[193] Jefferies KS. Solar Simulator for Solar Dynamic Space Power System Testing. ASME Int. Sol. Energy Conf., San Francisco, California, USA: 1994, p. 1-8.

[194] Schunk LO, Lipiński W, Steinfeld A. Heat transfer model of a solar receiver-reactor for the thermal dissociation of $\mathrm{ZnO}$-Experimental validation at $10 \mathrm{~kW}$ and scale-up to $1 \mathrm{MW}$. Chem Eng $\mathrm{J}$ 2009;150:502-8. doi:10.1016/j.cej.2009.03.012.

[195] Schunk LO, Haeberling P, Wepf S, Wuillemin D, Meier A, Steinfeld A. A Receiver-Reactor for the Solar Thermal Dissociation of Zinc Oxide. J Sol Energy Eng 2008;130:21009-021009-6. doi:10.1115/1.2840576.

[196] Nakakura M, Ohtake M, Matsubara K, Yoshida K, Cho HS, Kodama T, et al. Experimental demonstration and numerical model of a point concentration solar receiver evaluation system using a 30 kWth sun simulator. AIP Conf. Proc., vol. 1734, 2016, p. 30026. doi:10.1063/1.4949078.

[197] Gomez-Garcia F, Santiago S, Luque S, Romero M, Gonzalez-Aguilar J. A new laboratory-scale experimental facility for detailed aerothermal characterizations of volumetric absorbers. AIP Conf. Proc., vol. 1734, 2016, p. 30018. doi:10.1063/1.4949070.

[198] SpectroLab. XT Series Continuous Wave Solar Simulator Product Description. Sylmar, California, USA: 2010.

[199] SpectroLab. SpectroLab XT30 Solar 2016. http://engineering.case.edu/centers/sdle/node/13 (accessed November 9, 2016).

[200] Beal RM, Chow S, Guay FA, Graf E, Muron A, Yandt M, et al. High Intensity Light-Cycling of Hcpv Cell Assemblies Using the Xt-30 Solar Simulator. Photovolt. Modul. Reliab. Work. 2012, NREL; 2012.

[201] Andreev VM, Vlasov AS, Khvostikov VP, Khvostikova OA, Gazaryan PY, Sadchikov NA, et al. Solar thermophotovoltaic converter with fresnel lens and GaSb cells. Conf Rec 2006 IEEE 4th World Conf Photovolt Energy Conversion, WCPEC-4 2007;1:644-7. doi:10.1109/WCPEC.2006.279537.

[202] Andreev VM, Khvostikov VP, Rumyantsev VD, Khvostikova OA, Gazaryan PY, Vlasov AS, et al. Thermophotovoltaic Converters With Solar Powered. 20th Eur. Photovolt. Sol. Energy Conf., Barcelona Spain: 2005, p. 6-10.

[203] Shaughnessy BM, Toplis GM, Wright D. Thermal Testing of the Beagle 2 Mars Lander. 33rd Int. Conf. Environ. Syst. ICES 2003, Vancouver, BC; Canada: 2003, p. 179-84. doi:10.4271/200301-2462.

[204] Tolbert CM. Selection of solar simulator for Solar Dynamic Ground Test. Proc. Intersoc. Energy Convers. Eng. Conf., vol. 1, 1994.

[205] Shaltens RK, Boyle R V. Initial Results From the Solar Dynamic ( SD ) Ground Test Demonstration ( GTD ) Project at NASA Lewis. 30th Intersoc. Energy Convers. Eng. Conf., Orlando, Florida, USA: NASA; 1995, p. 363-8. 
[206] Kerslake TW, Mason LS, Strumpf HJ. High-flux, high-temperature thermal vacuum qualification testing of a solar receiver aperture shield. IECEC-97 Proc. Thirty-Second Intersoc. Energy Convers. Eng. Conf. (Cat. No.97CH6203), vol. 1, Honolulu, Hawaii, USA: IEEE; 1997, p. 440-5. doi:10.1109/IECEC.1997.659230.

[207] Mason LS, Shaltens RK, Espinosa WD. Experimental data for two different alternator configurations in a solar Brayton power system. IECEC-97 Proc. Thirty-Second Intersoc. Energy Convers. Eng. Conf. (Cat. No.97CH6203), vol. 1, Honolulu, Hawaii, USA: IEEE; 1997, p. 454-9. doi:10.1109/IECEC.1997.659232.

[208] Lin E, Stultz J. Cassini MLI blankets high-temperature exposure tests. 33rd Aerosp. Sci. Meet. Exhib., Reno, USA: American Institute of Aeronautics and Astronautics; 1995, p. 1-7. doi:10.2514/6.1995-633.

[209] Mattson Technology (MTSN). Acquisition of Vortek Industries Ltd 2005. http://www.wikinvest.com/stock/Mattson_Technology_(MTSN)/Acquisition Vortek Industries Ltd (accessed November 9, 2016).

[210] Emery KA. Solar simulators and I-V measurement methods. Sol Cells 1986;18:251-60. doi:10.1016/0379-6787(86)90124-9.

[211] Krusi P, Schmid R. The CSI $1000 \mathrm{~W}$ lamp as a source for solar radiation simulation. Sol Energy 1983;30:455-62.

[212] Terms R. Basic Radiometry for Stray Light Analysis. Stray Light Anal. Control, Bellingham, Washington USA: SPIE; 2013, p. 13-39. doi:10.1117/3.1000980.ch2.

[213] Badescu V. Modeling Solar Radiation at the Earth's Surface. Berlin, Heidelberg: Springer Berlin Heidelberg; 2008. doi:10.1007/978-3-540-77455-6.

[214] Gordon G. Interior Lighting for Designers. 5th ed. John Wiley \& Sons; 2015.

[215] Irwan YM, Leow WZ, Irwanto M, Fareq M, Amelia AR, Gomesh N, et al. Analysis air cooling mechanism for photovoltaic panel by solar simulator. Int J Electr Comput Eng 2015;5:636-43.

[216] Choit SH, Scottit SJ, Song KD, Ries H. Transpiring Cooling of a Scram-Jet Engine Combustion Chamber. Hampton, VA, USA: 1997.

[217] Bader R, Haussener S, Lipinski W. Optical Design of Multisource High-Flux Solar Simulators. J Sol Energy Eng 2015;137:21012-1-021012-9. doi:10.1115/1.4028702.

[218] Flesch PG. Light and Light Sources: High-Intensity Discharge Lamps. Springer-Verlag Berlin Heidelberg; 2006. doi:10.1007/978-3-540-32685-4.

[219] Severon B. Efficient lighting for high-speed imaging on vehicle safety test applications. Crash Netw 2016:1-5. doi:10.1117/12.424307.

[220] Davidson MW. Tungsten-Halogen Incandescent Lamps. Carl Zeiss Microsc Online Campus $2016 . \quad$ http://zeiss-campus.magnet.fsu.edu/articles/lightsources/tungstenhalogen.html (accessed November 9, 2016).

[221] Baines F. The ReptileUV Mega-Ray Series of Mercury Vapour Lamps 2006. http://reptileuv.tripod.com/MegaRayNarrowFloodReport2006.htm (accessed November 9, 2016).

[222] Pérez-Higueras P, Fernández EF. High Concentrator Photovoltaics: Fundamentals, Engineering and Power Plants. Springer; 2015.

[223] Wolf AT. Durability of Building Sealants. RILEM Publications; 1999. 
[224] The National Institute for Occupational Safety and Health (NIOSH) recommendations. Criteria for a Recommended Standard: Occupational Exposure to Ultraviolet Radiation. 1972.

[225] Hall R. Sealed beam discharge lamps for solar simulators. In: Commission TE, Aranovich E, Gillett B, editors. Work. Sol. Simulators, Ispra, Italy: Commission of the European Communities Joint Research Centre Ispra Establishment; 1982, p. 11-9.

[226] Osram. Product datasheet: XBO Xtreme Life, Xenon short-arc lamps for cinema projection 2016:1-5. http://www.osram.com/osram_com/products/lamps/specialty-lamps/xbo/xbo-xtremelife/index.jsp (accessed June 8, 2017).

[227] Osram. Product datasheet: Xenon short-arc lamps without reflector 2016:1-5. http://www.osram.com/osram_com/products/lamps/specialty-lamps/xbo/xbo/index.jsp (accessed June 8, 2017).

[228] GE product datasheet. GE 300W ELH Model 2016. http://catalog.gelighting.com/apac/lamp/showbiz-lamps/projection/f=multi-mirror-quartzlineprojection-mr16/p=38476/?l=en\&r=apac (accessed November 9, 2016).

[229] Philips. Product datasheet: Halogen High Voltage SE (Film/Studio) 2015:1-3. http://download.p4c.philips.com/lfb/c/comf-2756/comf-2756_pss_en_aa_001.pdf (accessed June 8, 2017).

[230] Philips. Product datasheet: Xenon Entertainment (Follow Spots) 2015:1-2. http://download.p4c.philips.com/lfb/c/comf-2128/comf-2128_pss_en_aa_001.pdf (accessed June 8, 2017).

[231] Philips. Product datasheet: High Pressure Metal Halide Lamps - Double-Ended Metal Halide 2015:1-2. http://download.p4c.philips.com/lfb/c/comf-1450/comf-1450_pss_en_aa_001.pdf (accessed June 8, 2017).

[232] Sliney DH, Mellerio J. Safety with Lasers and Other Optical Sources: A Comprehensive Handbook. 1st Ed. Springer US; 1980.

[233] Brennesholtz MS, Stupp EH. Projection Displays. 2nd Ed. Wiley-Blackwell; 2008.

[234] Philips. Product datasheet: HPI-T 2000W/646 E40 220V CRP/4 2016:1-3. http://download.p4c.philips.com//fb/f/fp-928073609231/fp-928073609231_pss_en_gb_001.pdf (accessed June 8, 2017).

[235] Philips. Philips Entertainment Lamps catalogue 2016.

[236] Philips. The Ultimate Experience with Philips Cinema Xenon Lamps 2009:1-20. http://www.lighting.philips.com/pwc_li/main/subsites/special_lighting/assets/Cinema_brochure_ Febr_2011.pdf (accessed June 8, 2017).

[237] Any Lamp BV. Philips HPI-T 2000W 642 E40 220V 2016. https://www.any-lamp.co.uk/philipshpi-t-2000w-646-e40-220v-crp-master (accessed November 9, 2016).

[238] Get a Lamp S.C.P. PHILIPS $6994 Z$ 2000W G38 $230 \mathrm{~V}$ 1CT 2016. https://www.getalamp.co.uk/philips-6994z-2000w-g38-230v-1ct.html (accessed November 9, 2016).

[239] Theatrical Bulb Supply. Philips LTIX-2000W/H Xenon Lamp 2016. http://www.theatricalbulbsupply.com/xenon-short-arc-lamps/philips-lti/xenon-entertainmentfollow-spots/philips-Itix-2000w-h-xenon-lamp/ (accessed November 9, 2016).

[240] Any Lamp BV. Philips SI 52 220-240V 50/60Hz 2016. https://www.any-lamp.co.uk/philips-si-52220-240v-50-60hz (accessed November 9, 2016). 
[241] Any Lamp BV. Philips HID-HighPower BHL 2000 L78 2017. https://www.any-lamp.co.uk/philipshid-highpower-bhl-2000-178-230-240v-50hz-hp-317 (accessed October 25, 2017).

[242] Powergems Limited. 2000W Xenon Electronic Ballast 2017. https://powergems.com/product/xm200-2000w-xenon-electronic-ballast/ (accessed October 27, 2017).

[243] Aldrich R, Parello J. IP-Enabled Energy Management: A Proven Strategy for Administering Energy as a Service. Indianapolis, Indiana: Wiley Publishing; 2010.

[244] Bortolini M, Gamberi M, Graziani A. Ray-tracing model and Monte Carlo simulation for the design of the concentrating solar simulator reflector. Int J Mod Eng Res 2013;3:13-5.

[245] Goswami Y, Kreith F. Energy Conversion. 1st Ed. CRC Press; 2008.

[246] Kalogirou SA. Solar Energy Engineering: Processes and Systems. 2nd Ed. Elsevier Inc.; 2014. 
2018-04-24

Light source selection for a solar simulator for thermal applications: A review

Tawfik, Mohamed M.

Elsevier

Tawfik M, Tonnellier X, Sansom C. (2018) Light source selection for a solar simulator for thermal applications: A review. Renewable and Sustainable Energy Reviews, Volume 90, July 2018, pp. 802-813

https://doi.org/10.1016/j.rser.2018.03.059

Downloaded from Cranfield Library Services E-Repository 